
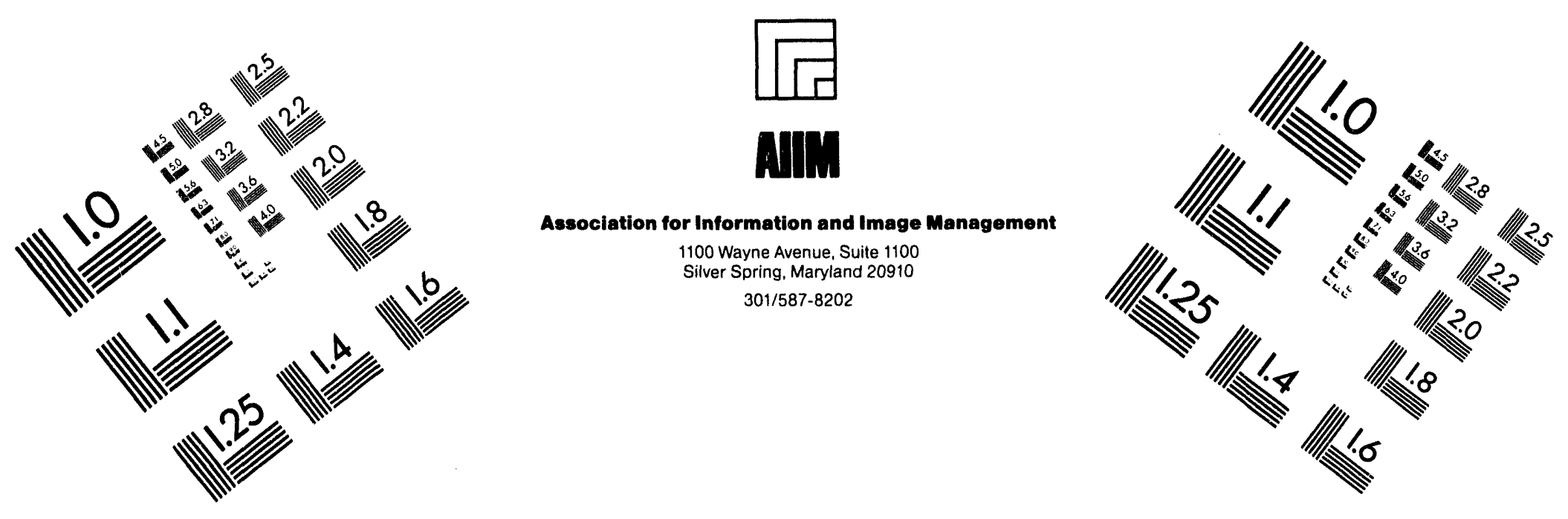

Centimeter

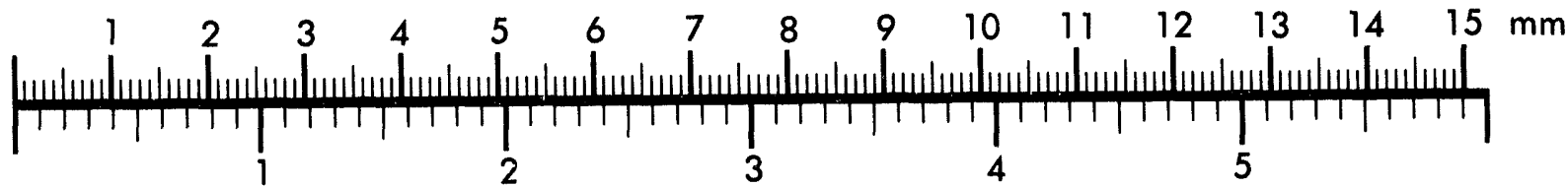
Inches
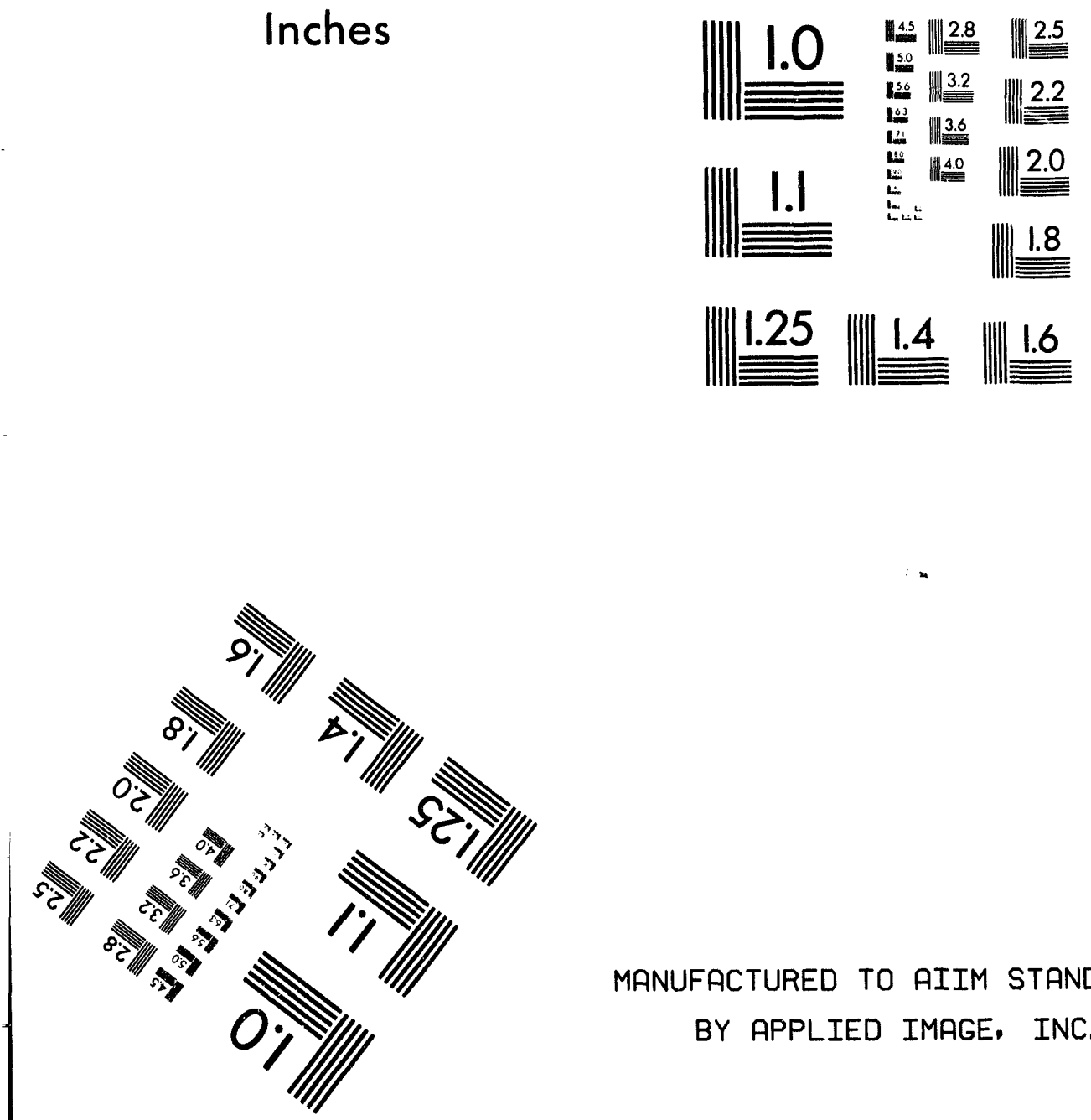

MANUFACTURED TO AIIM STANDARDS

BY APPLIED IMAGE. INC.

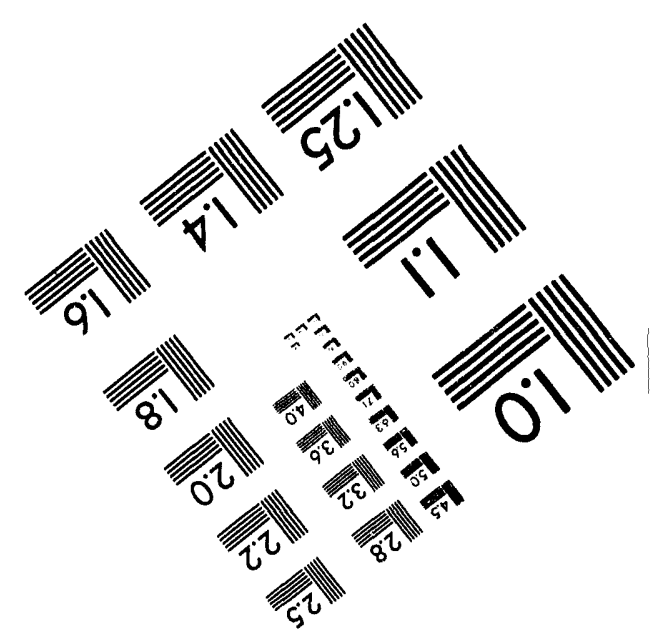



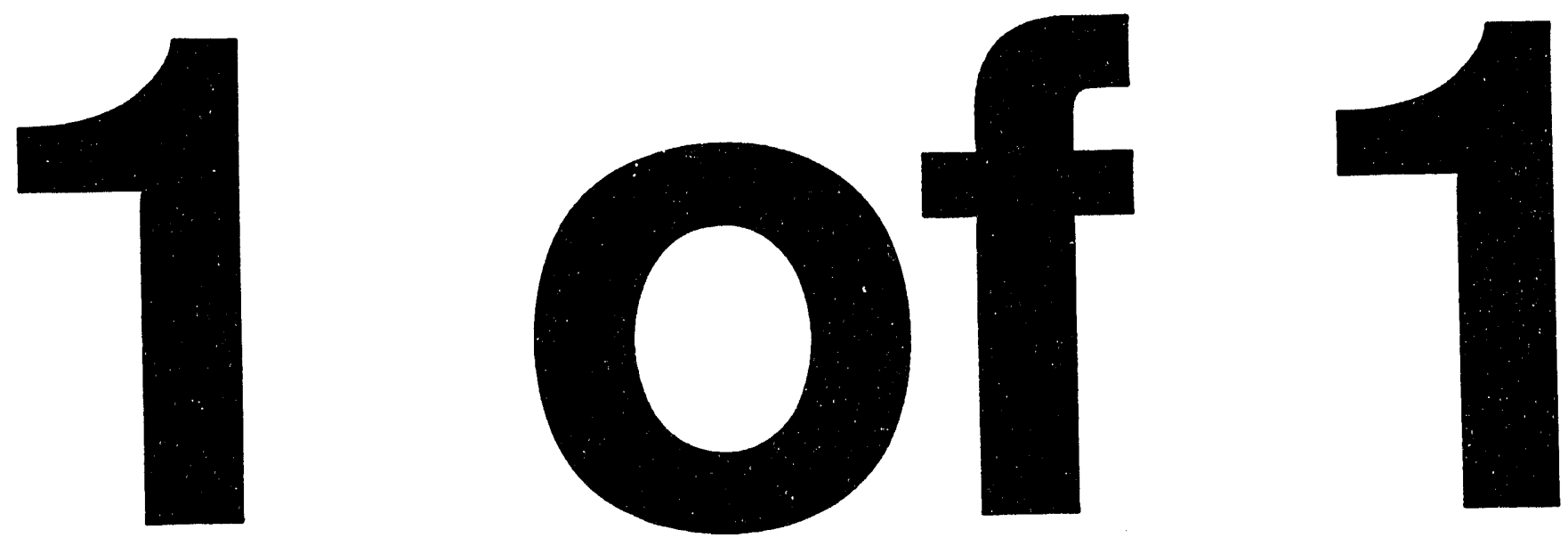
ATLAS Internal Vote

TILECAL-NO-020

21 June 1994

Atlas Number

ANL-HEP-TR-94-48

\title{
Argonne Mechanical Design Proposal \\ For the ATLAS Hadron Calorimeter
}

\author{
Presented by
}

Norman F. Hill, Lead Engineer

High Energy Physics Division

Argonne National Laboratory

In Collaboration with

Brandeis University, University of Chicago, Harvard University, University of Illinois, and Michigan State University

ATLAS Engineering Meeting

CERN Laboratory

Geneva, Switzerland

RECEIVED
SEP O 91994
OSTI

21 June 1994 


\section{DISCLAIMER}

This report was prepared as an account of work sponsored by an agency of the United States Government. Neither the United States Government nor any agency thereof, nor any of their employees, makes any warranty, express or implicd, or assumes any legal liability or responsibility for the accuracy, completeness, or usefulness of any information, apparatus, product, or process disclosed, or: represents that its use would not infringe privately owned rights. Reference herein to any specific commercial product, process, or service by trade name, trademark, manufacturer, or otherwise does not necessarily constitute or imply its endorsement, recommendation, or favoring by the United States Government or any agency thereof. The views and opinions of authors expressed herein do not necessarily state or reflect those of the United States Government or any agency thereof. 


\section{Argonne Proposal}

What is unique about the Argonne proposal?

- By overlapping the spacer plates the compression load is carried through the module without affecting the scintillator slots.

- $\quad$ Flat thin straps are used in place of tie rods.

- A supermodule is constructed of six 1 meter modules.

- It is not necessary to drill holes through the scintillator.

- Absorber structure van be assembled independent of scintillator.

- Straps provide better load distribution across the plates.

- This design, as currently drawn, does not include internal sourcing, but does not preclude it being used. 


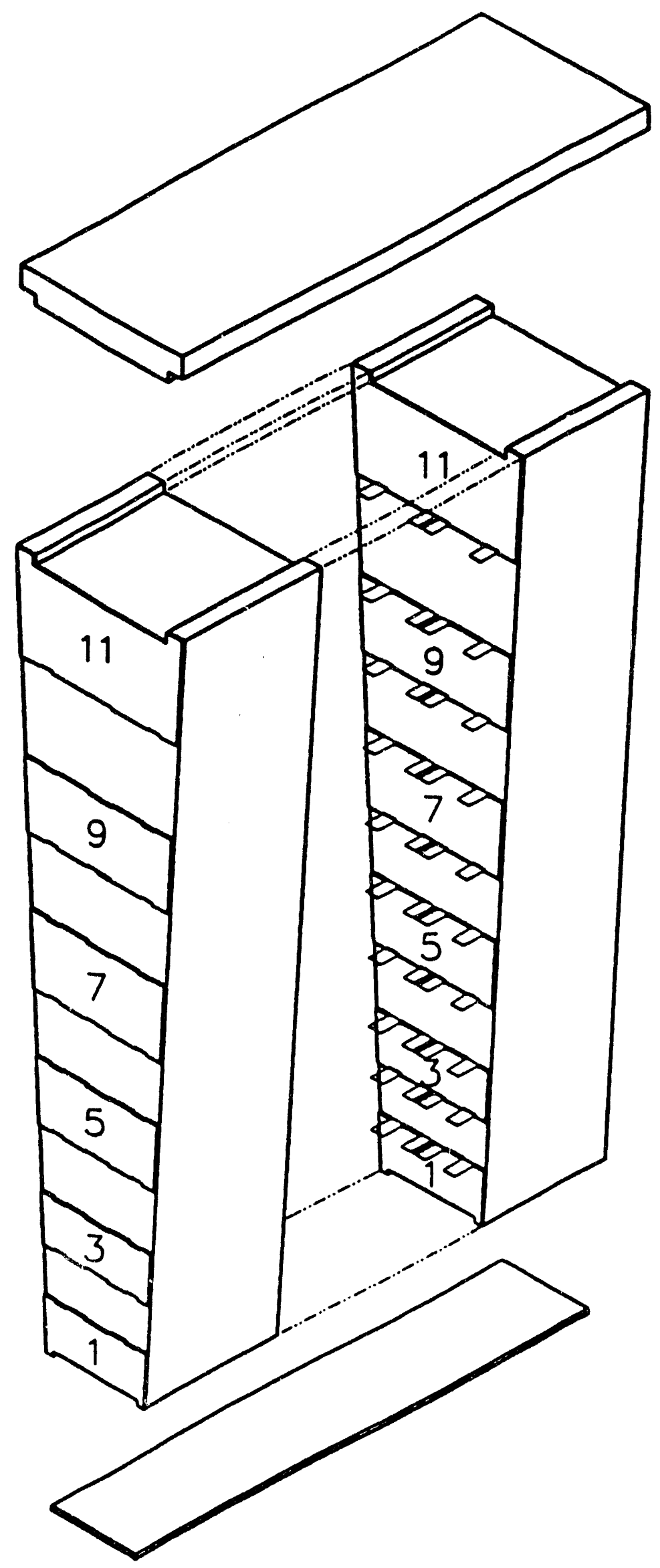

One Meter Module Split to Show Strap Positions 


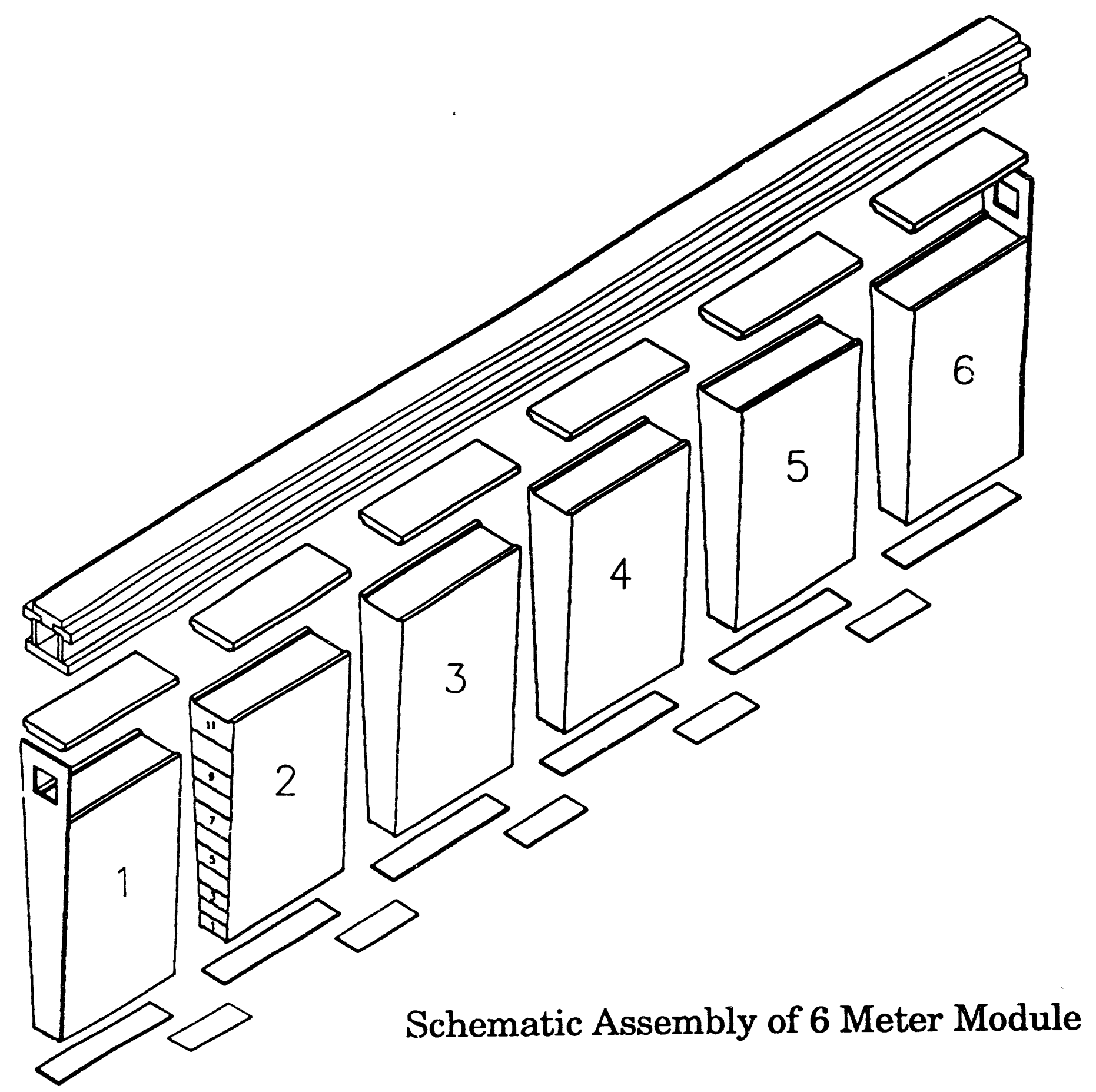




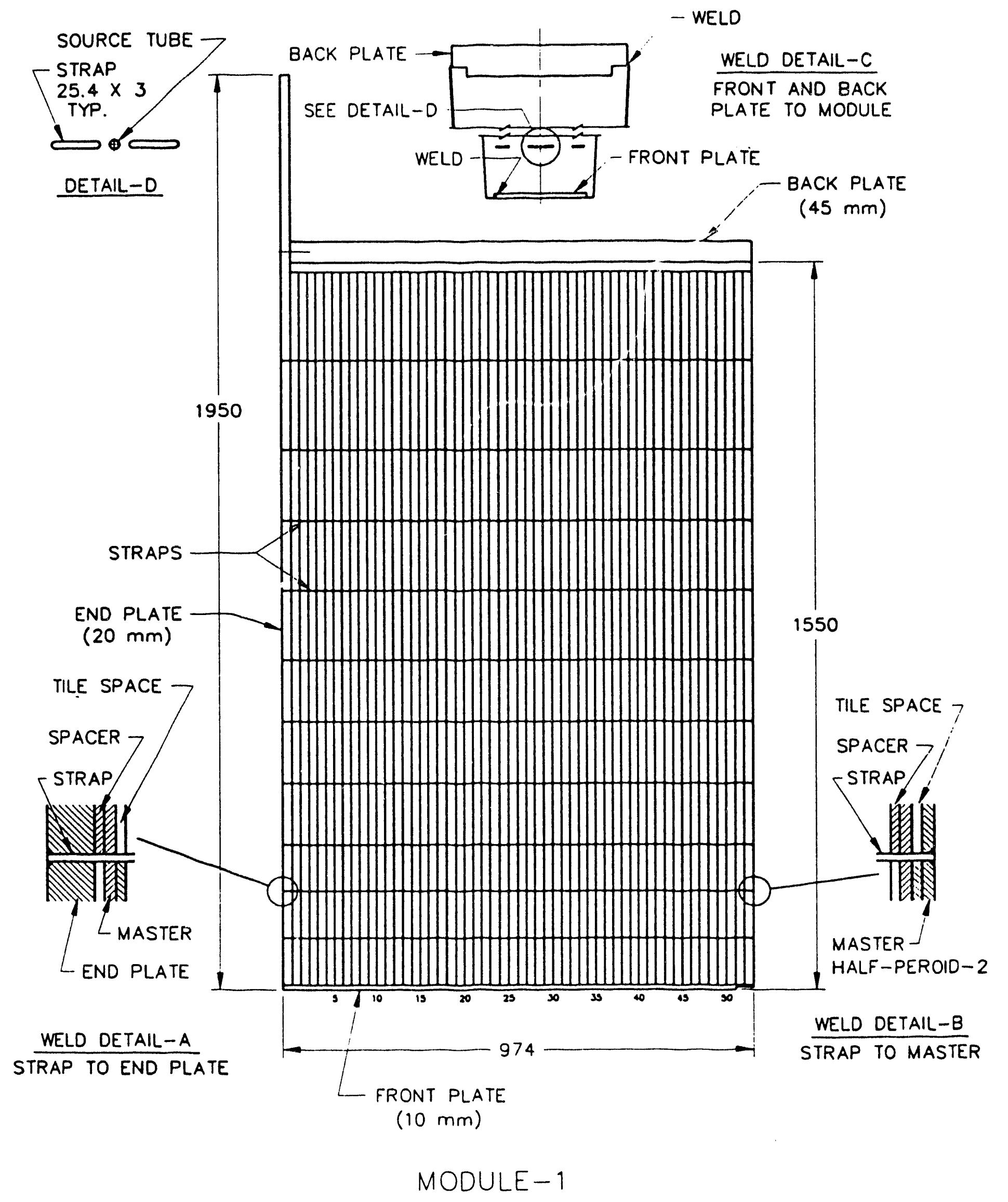


- WELD
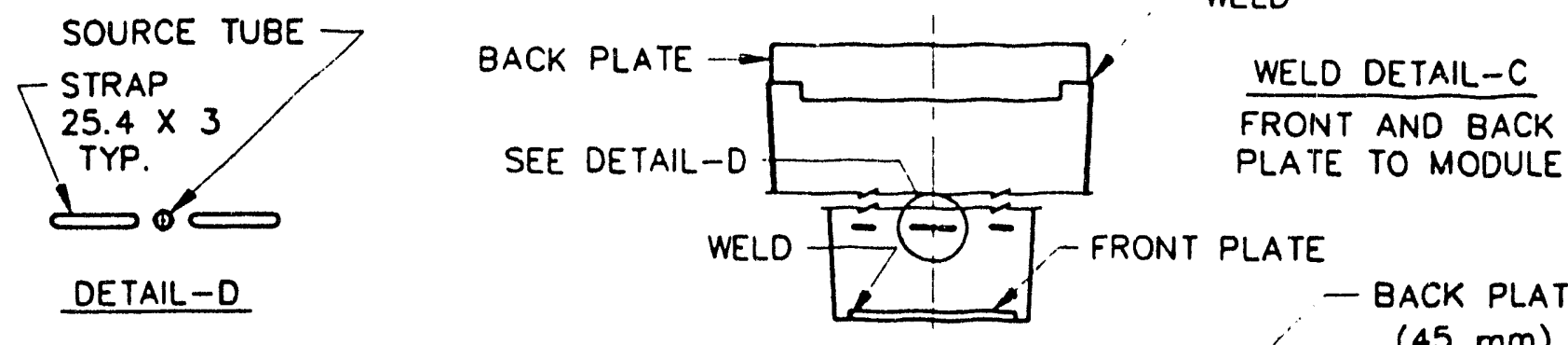

PLATE TO MODULE

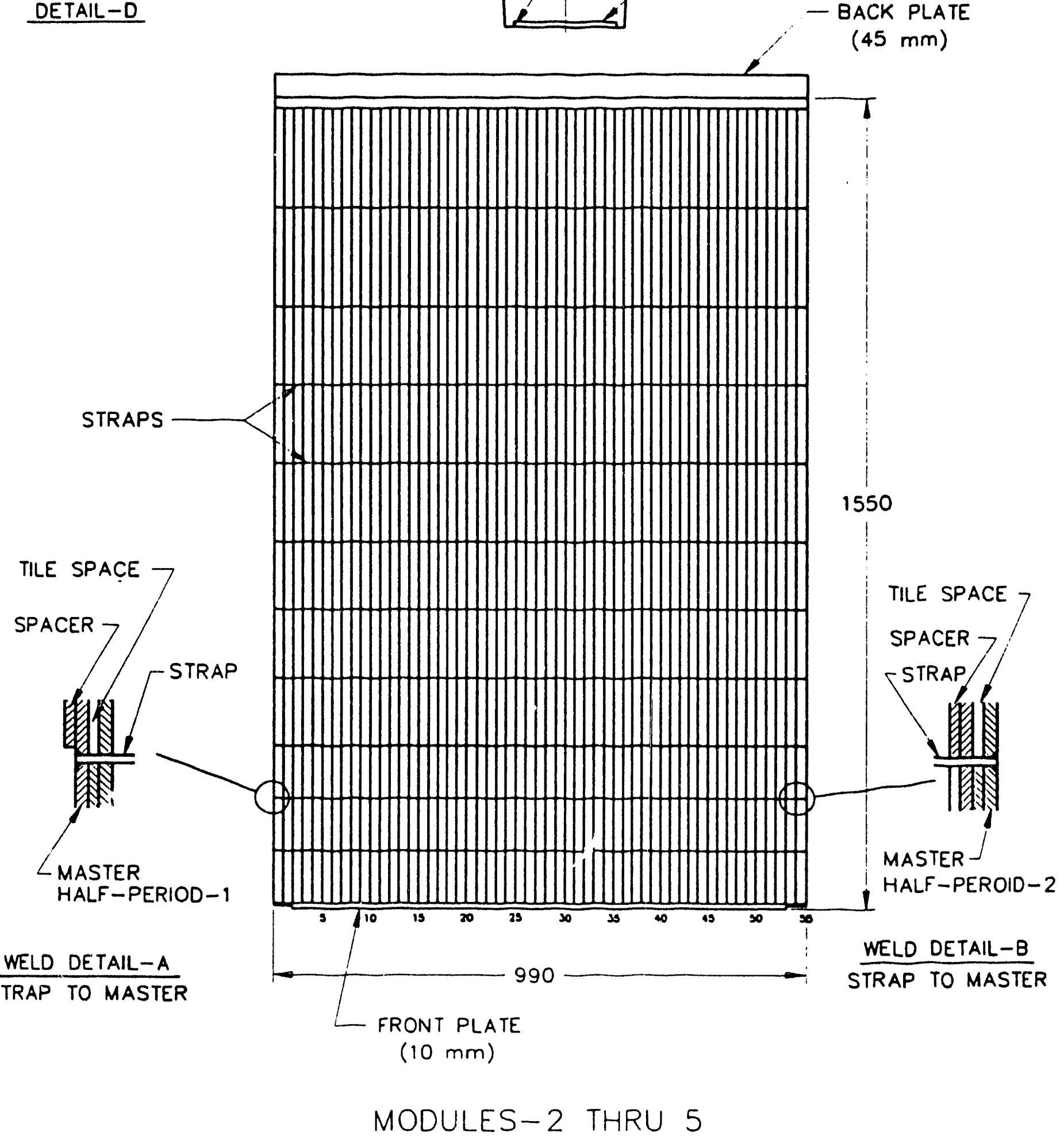




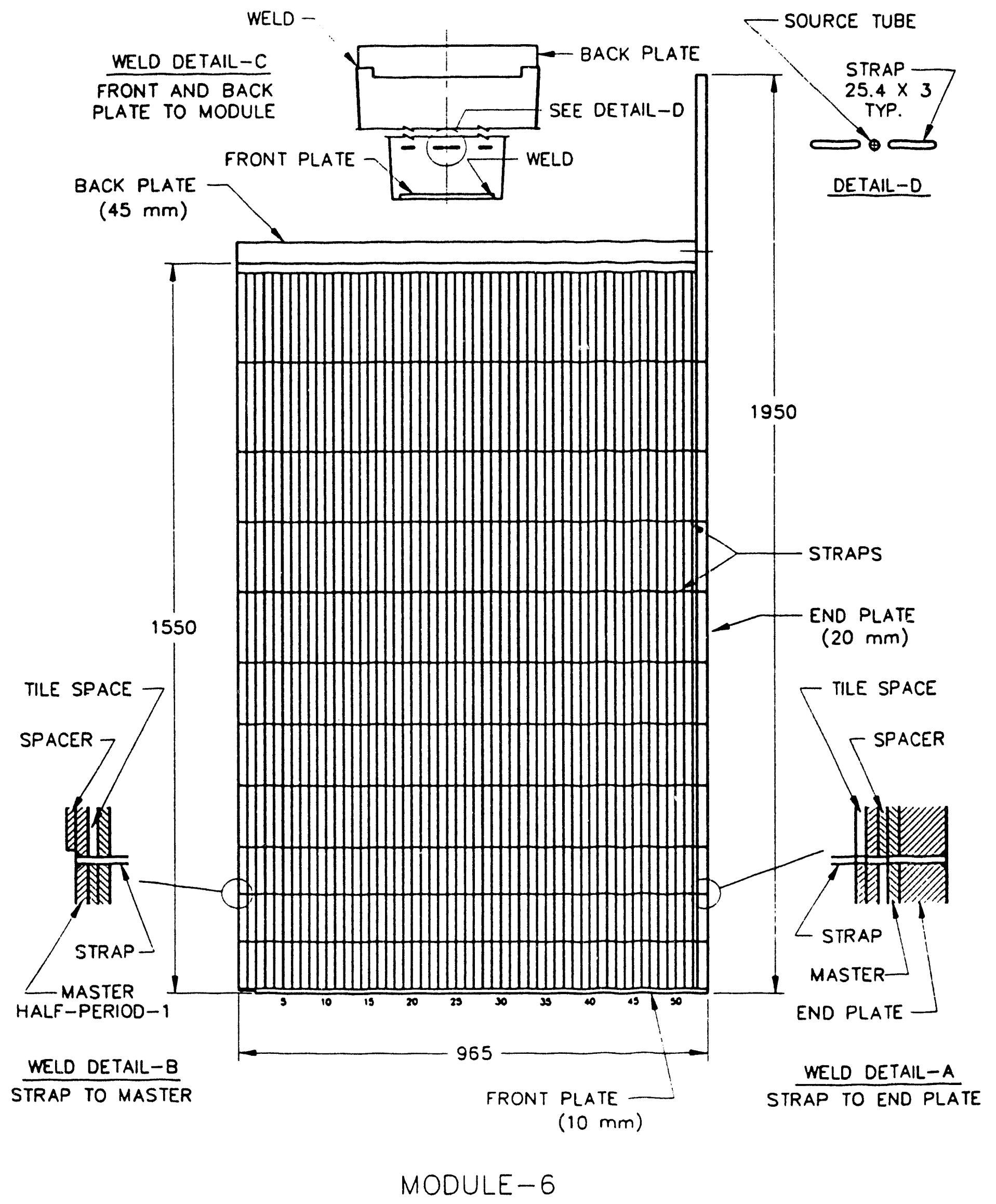



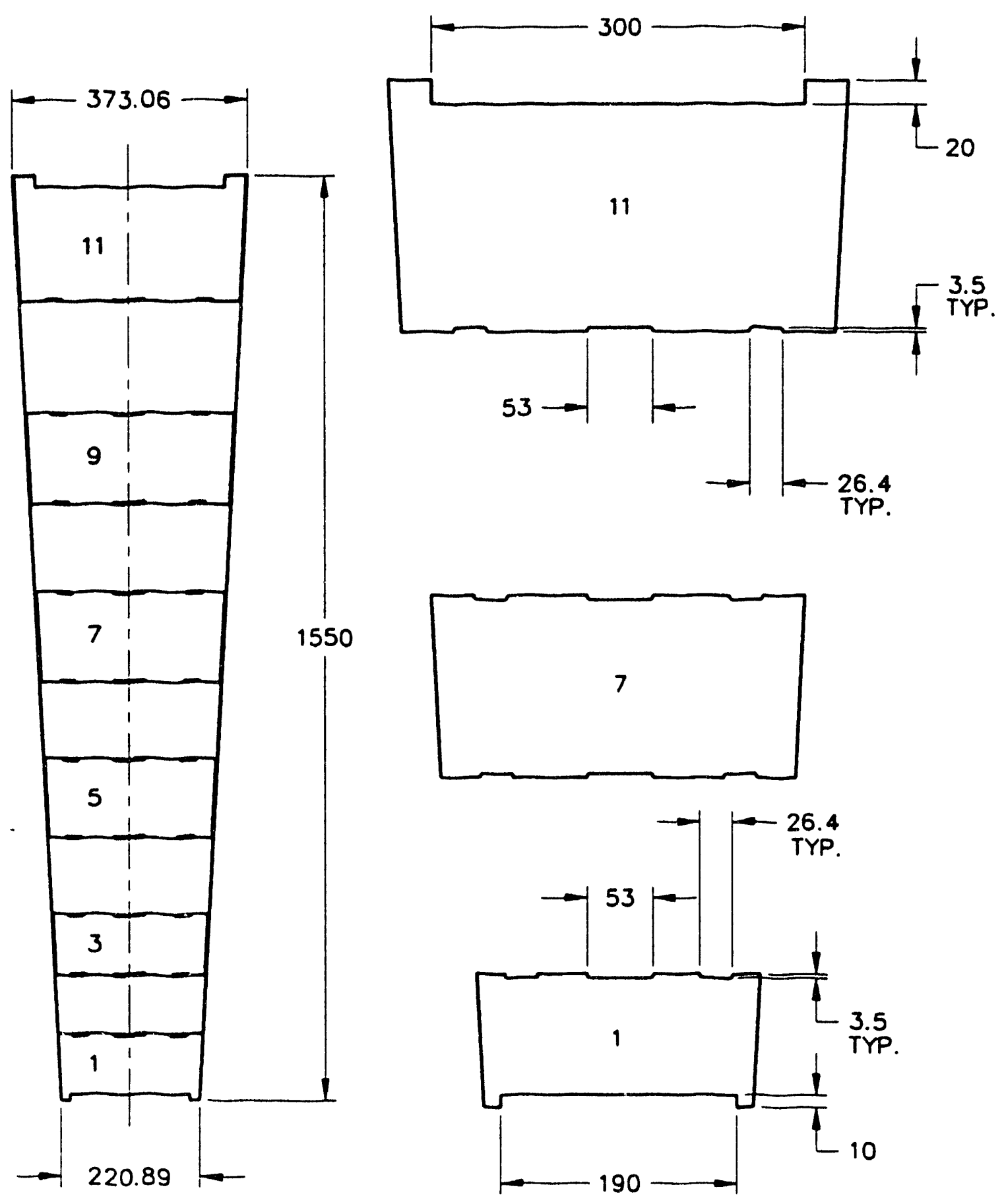

TYP. SPACERS

HALF-PERIOD-1 


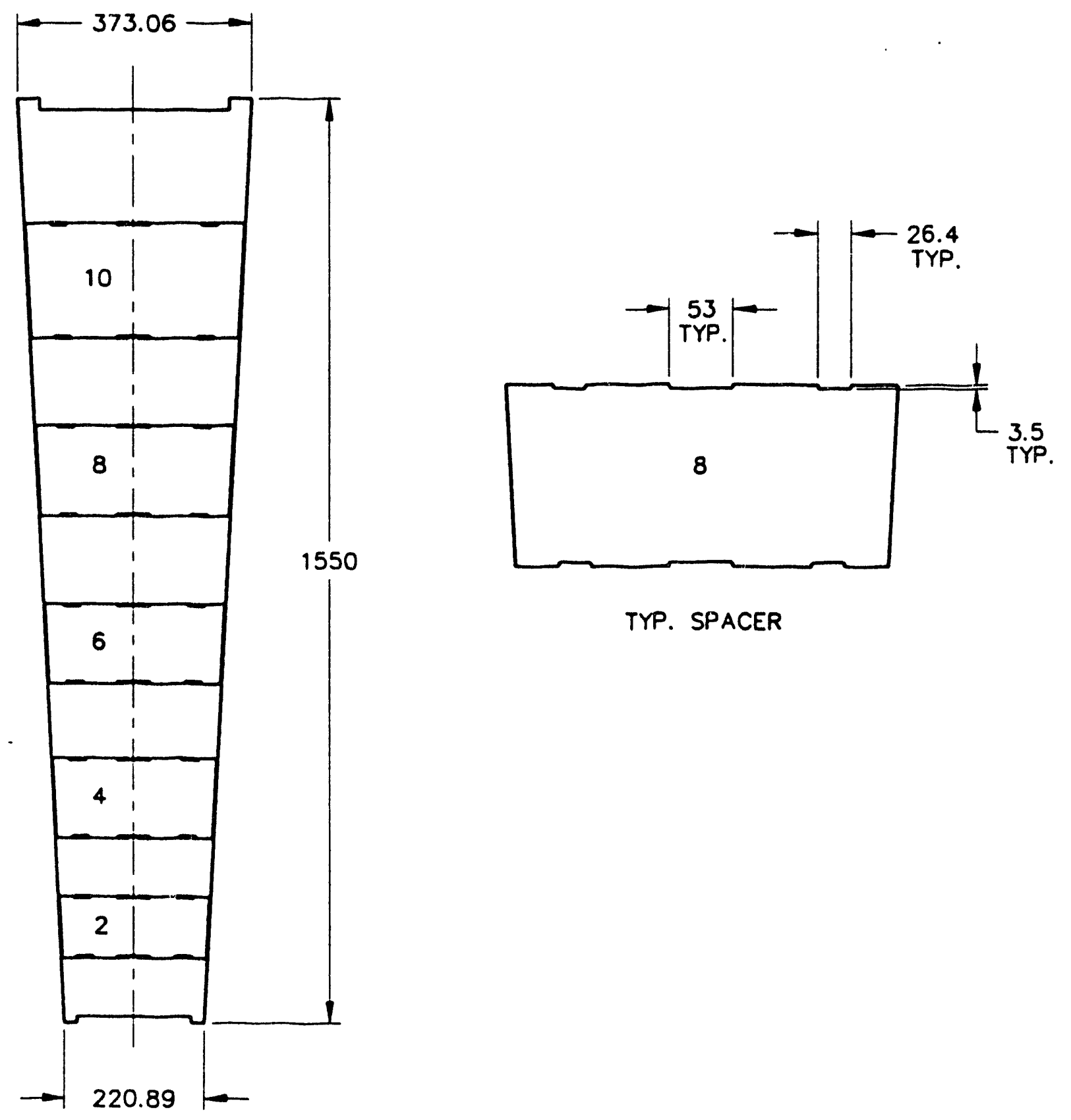

HALF-PERIOD - 2 


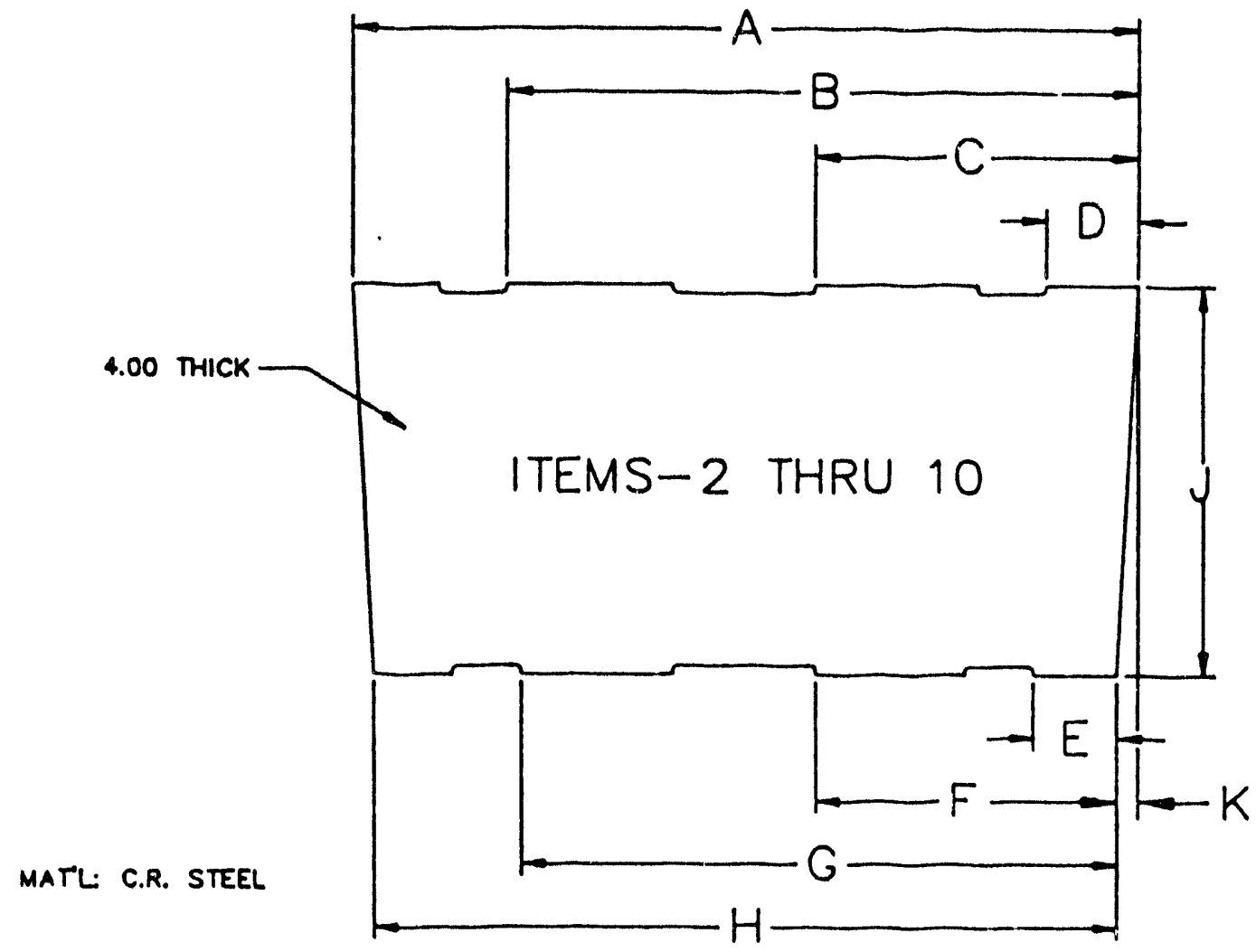

atras

MODULE ASSY.

PLATE-SPACER

AT 10-1-1 THRU 11

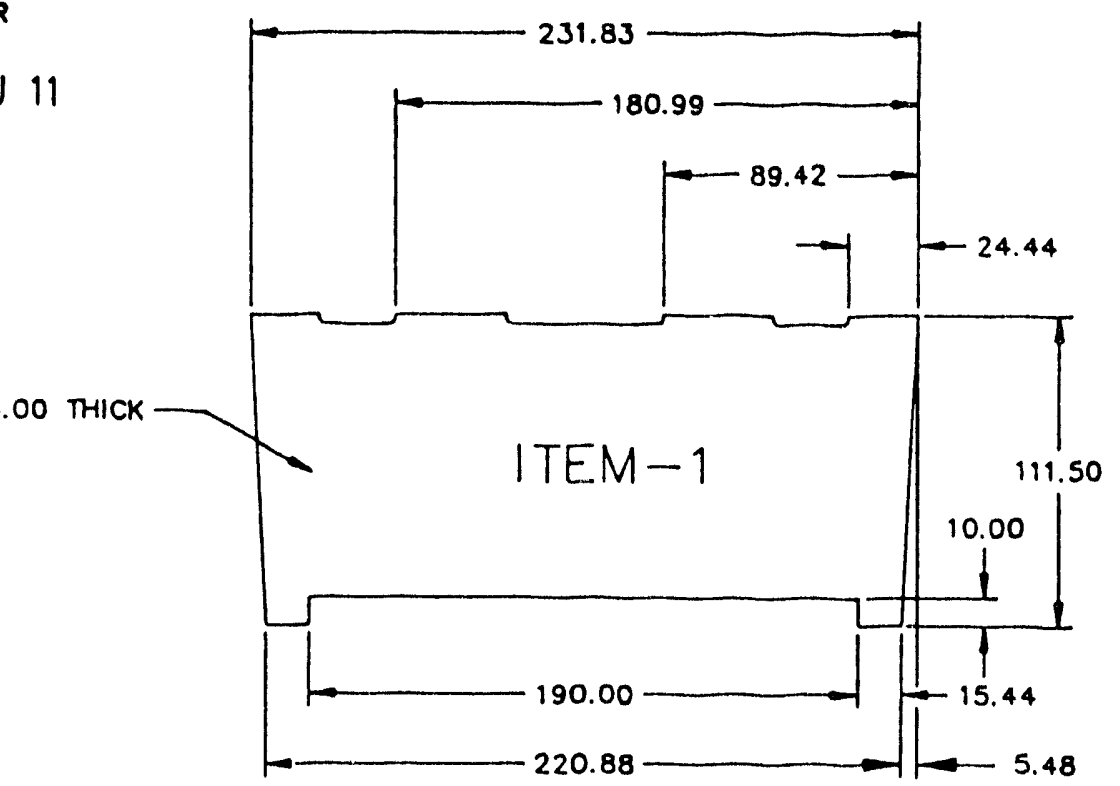




\begin{tabular}{|c|c|c|c|c|c|c|c|c|c|c|c|}
\hline IIEN No. & DEEO & om. - A & orm.-B & ons-C & ons.-D & On.-E & Dim.-F & onm. $-G$ & om.-H & OM. $-J$ & OIM. $-K$ \\
\hline 1 & 328 & & & & & & & & & & \\
\hline 2 & 325 & 237.64 & 187.22 & 92.32 & 24.02 & 2289 & 87.26 & 178.84 & 227.53 & 103.00 & 5.05 \\
\hline 3 & 326 & 247.46 & 195.44 & 97.23 & 25.62 & 23.88 & 92.18 & 187.07 & 237.35 & 103.00 & 5.05 \\
\hline 4 & 325 & 280.22 & 206.14 & 103.61 & 27.68 & 25.47 & 97.08 & 195.29 & 247.16 & 133.00 & 6.53 \\
\hline $\mathbf{s}$ & 326 & 272.90 & 216.8J & 110.00 & 29.78 & 27.54 & 103.46 & 205.99 & 259.93 & 133.00 & 6.53 \\
\hline 6 & 323 & 205.75 & 227.33 & 116.38 & 31.82 & 29.61 & 109.84 & 216.68 & 272.69 & 133.00 & 6.53 \\
\hline 7 & 326 & 300.46 & 239.87 & 123.74 & 34.21 & 31.67 & 116.22 & 227.38 & 285.45 & 153.00 & 7.51 \\
\hline 8 & 325 & 315.20 & 252.20 & 131.10 & 36.60 & 34.06 & 123.59 & 239.72 & 300.18 & 153.00 & 7.51 \\
\hline 2 & 328 & 329.93 & 264.54 & 138.46 & 38.98 & 36.45 & 130.96 & 252.06 & 314.91 & 153.00 & 7.31 \\
\hline 10 & 325 & 340.50 & 280.18 & 147.80 & 42.01 & 38.84 & 138.32 & 264.40 & 329.64 & 193.00 & 9.47 \\
\hline 11 & 326 & & & & & & & & & & \\
\hline
\end{tabular}

MATL: C.R. STH'S

ARAS

MOOULE ASSY.

PLATE-SPACER

AT 10-1-1 THRU 11

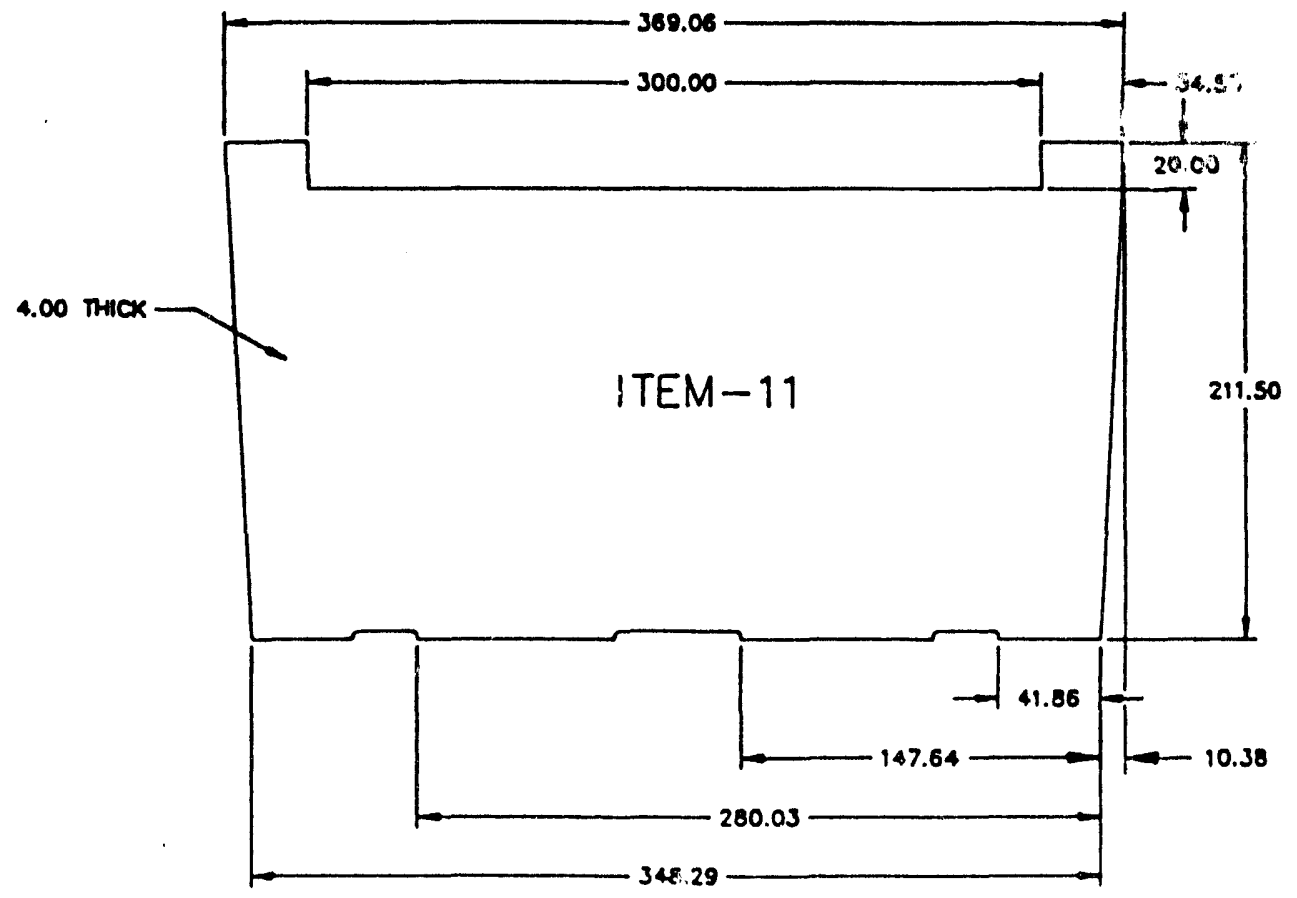

DIMENSIONS ARE IN mm.

CENTER SLOT

2-REO'O PER SPACER FOR ITEMS-2 THRU 10 I-REO'O. PER SPACER FOR ITEMS-I AND 11
END SLOT

4-REO'D PER SPACER FOR ITEMS-2 THRU 10 2-REO'O. PER SPACER 2-REQD. PER SPACER
FOR ITEMS-1 AND 11 


\section{CERN Tile-Cal Questions to be Answered}

1. What are the rod and strap stresses in both designs?

2. How would the spacers and tiles be located in both designs?

3. How precise could the slots for the straps be manufactured and located?

4. Provide a preliminary design and costing of the assembly tooling for both designs.

5. What is the welding procedure and possible weld distortions in both designs?

6. If the spacers are tack welded to the master plates, will there be damage to the surface that will interfere with the tile?

7. How will sub-modules be assembled together into a full module, and what are the tolerances that can be achieved in the final assembly?

8. How would the straps be tensioned and welded? 


\title{
Question \# 1
}

\author{
What are the rod and strap stresses in both designs \\ (1 meter submodules and 6 meter modules)?
}

The strap and rod stresses have been calculated in three different ways:

- Assuming .5 MPa, as specified in the Alstom feasibility study.

- Assuming single node out of plane surfaces on plates.

- Assuming multinode out of plane surfaces for plates. 


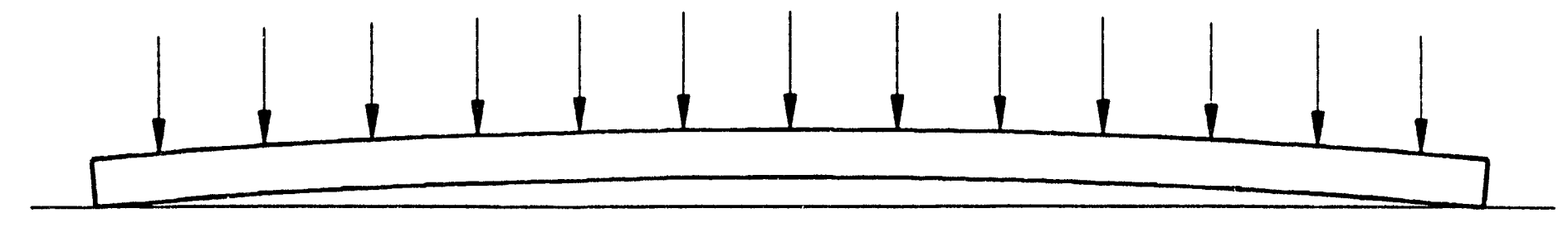

Single Node

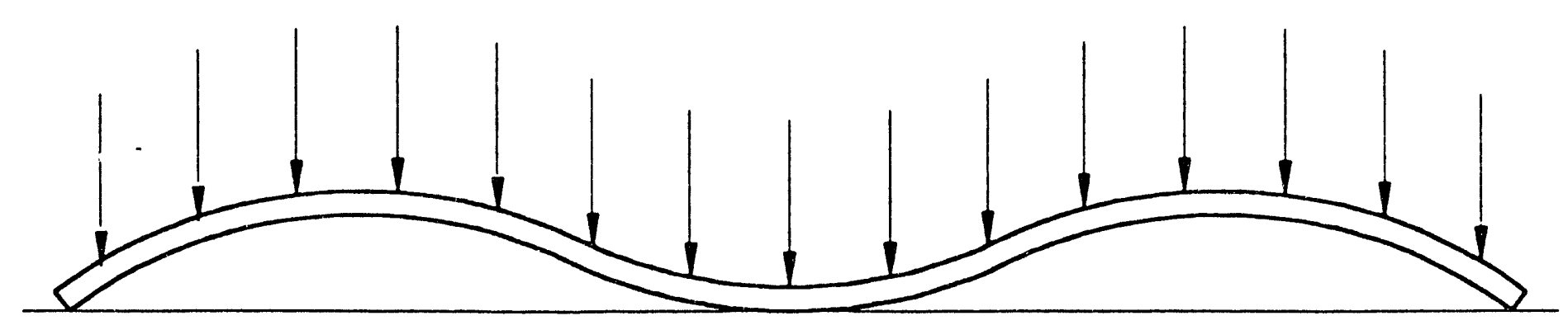

Multinode 


\section{Summary of Rod/Strap Stress and Deformation}

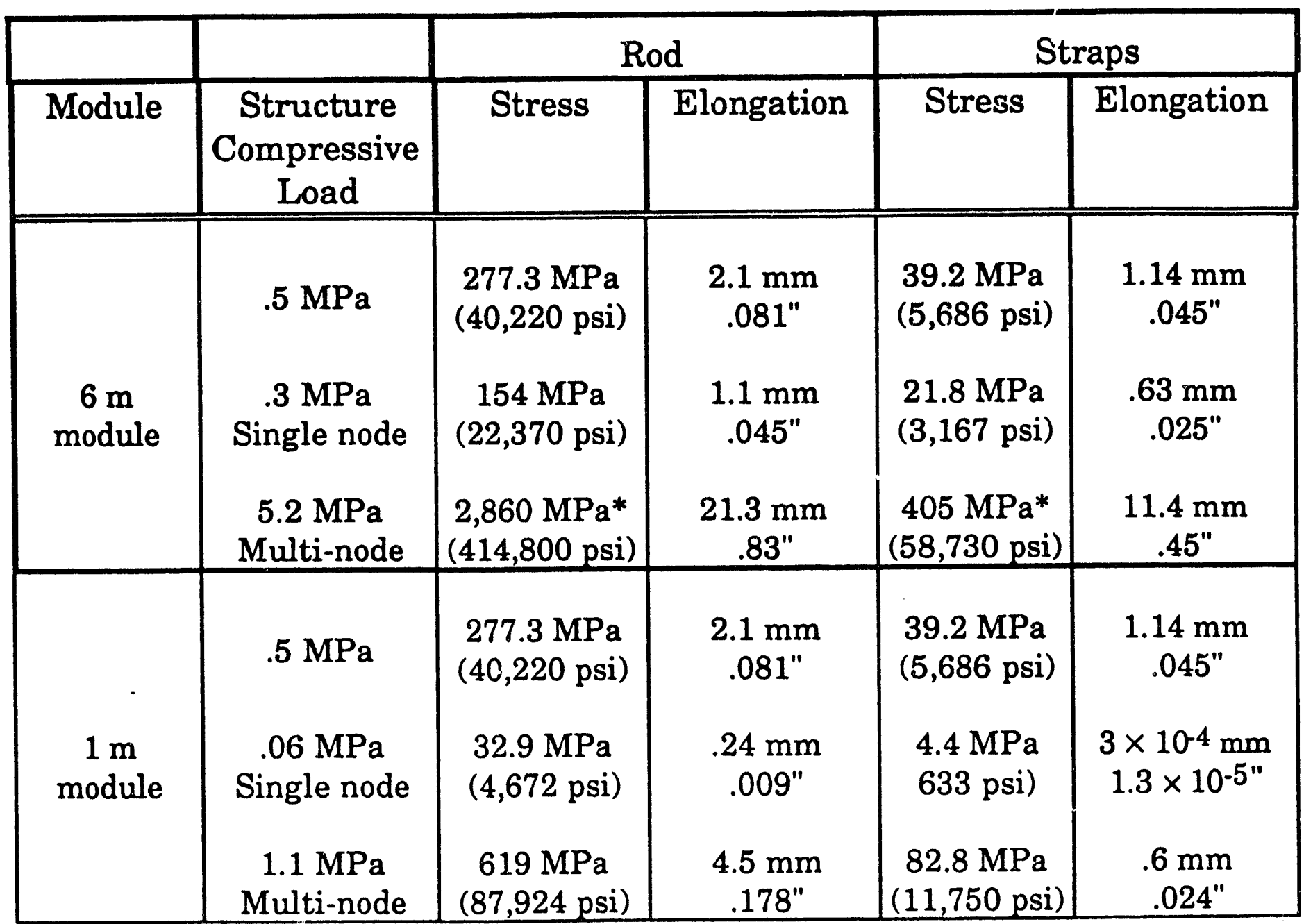

* Material will yield. 


\section{Question \# 2}

How would the spacers and tiles be located in both designs?

- The spacers and tiles would be located using the same methods in both the 6 meter and 1 meter submodule design.

- The spacers are located using fixturing.

- The tiles are located by the straps radially and by clips in $\phi$. 


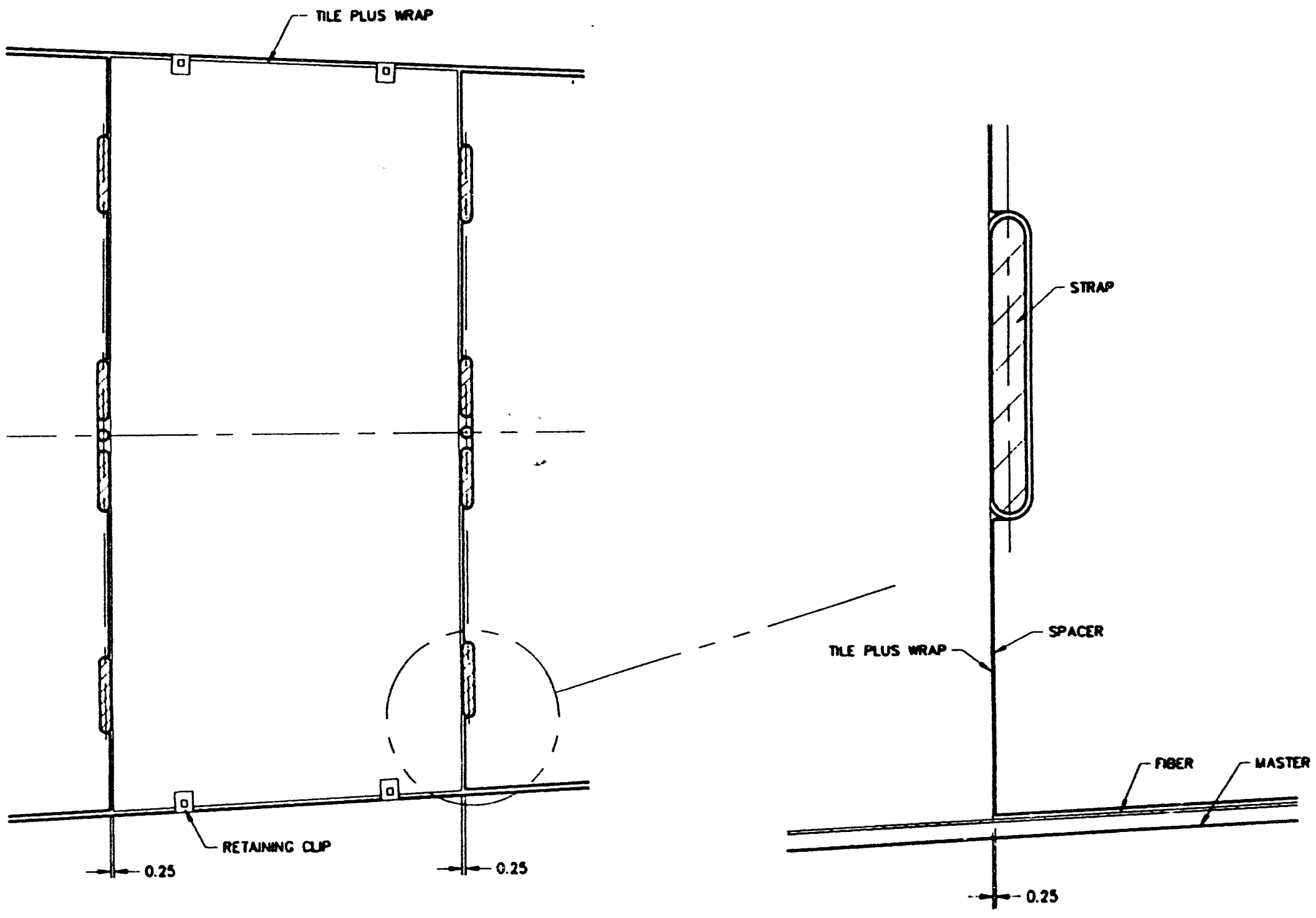

RADIAL TILE POSITION 

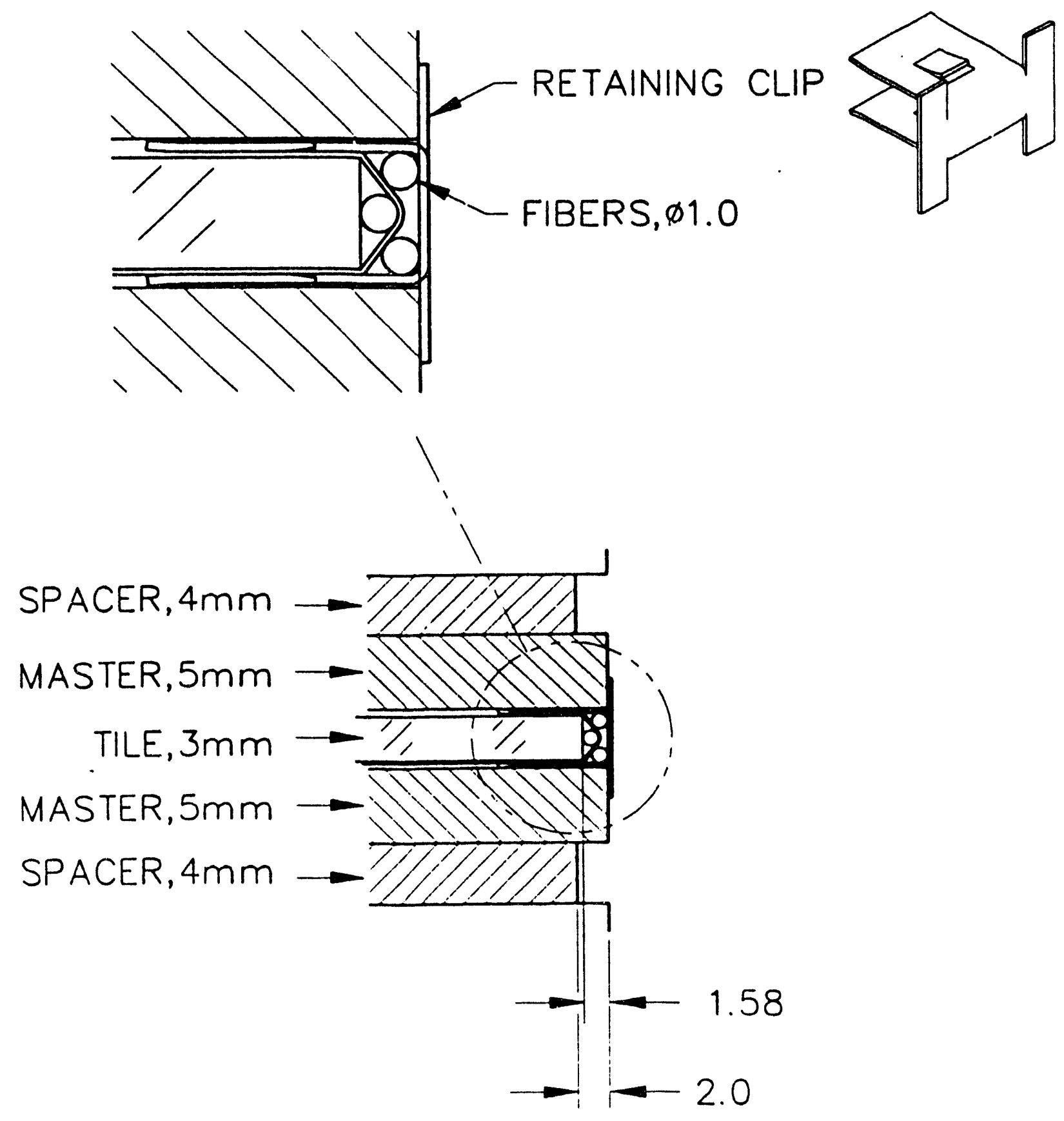

FIBER ARRANGEMENT (IN UPPER TILES) 


\section{Question \# 3}

How precise could the slots for the straps be manufactured and located?

- The slots can be located in $\mathrm{Z}$ and in $\phi$ to \pm 0.25 millimeters. 


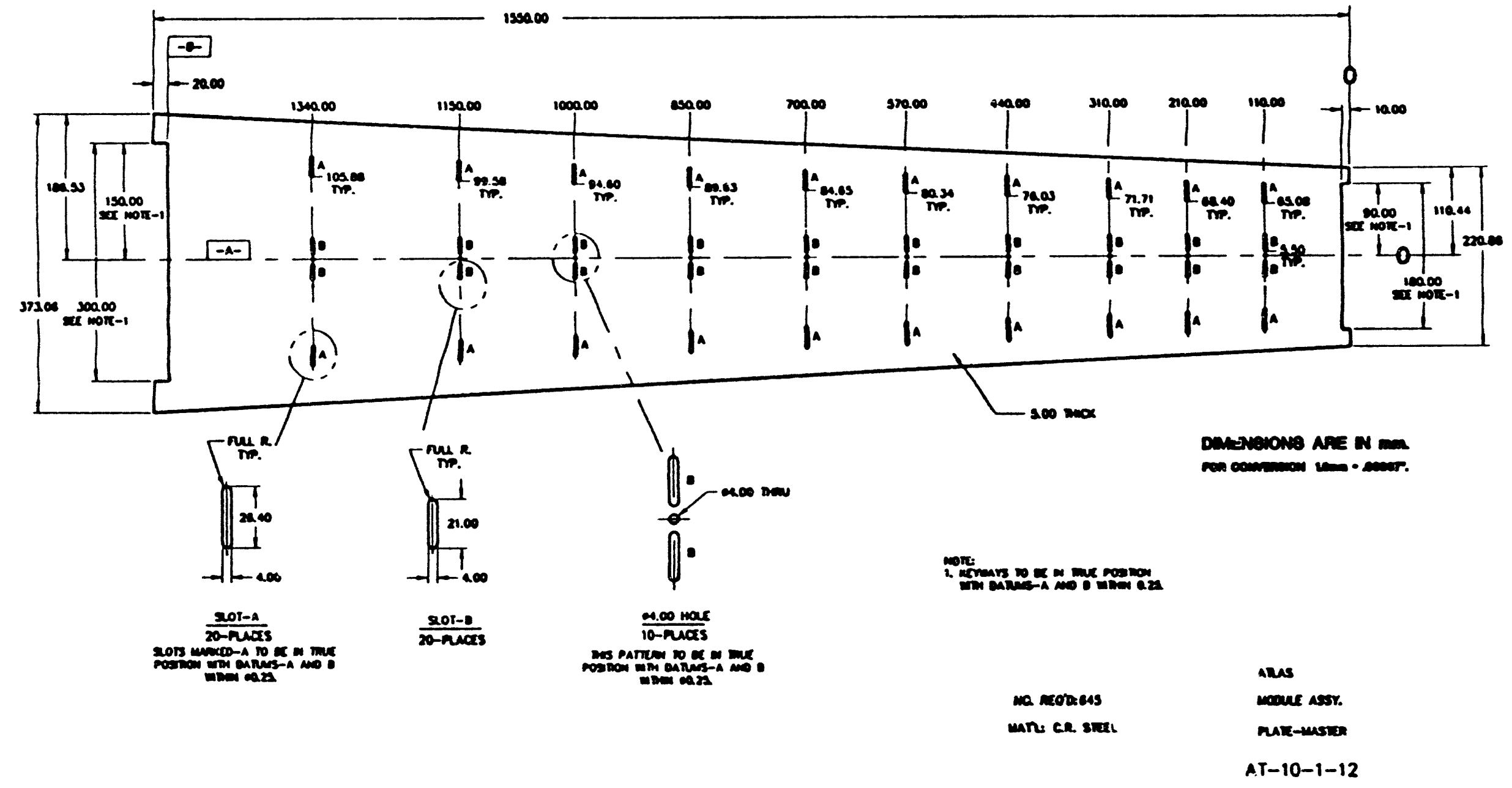

Master Plate Slot Position Tolerances 


\section{Question \# 4}

Provide a preliminary design and costing of the assembly tooling for both designs.

- The assembly fixturing consists of two parts:

-- Fixturing for $1 / 2$ period subassembly.

-- Fixture for stacking and welding the submodule.

- The estimated cost for tooling:

-- $\$ 15,000.00$ USD for $1 / 2$ period fixture.

-- $\quad \$ 150,000.00$ USD for stacking and welding fixture. 


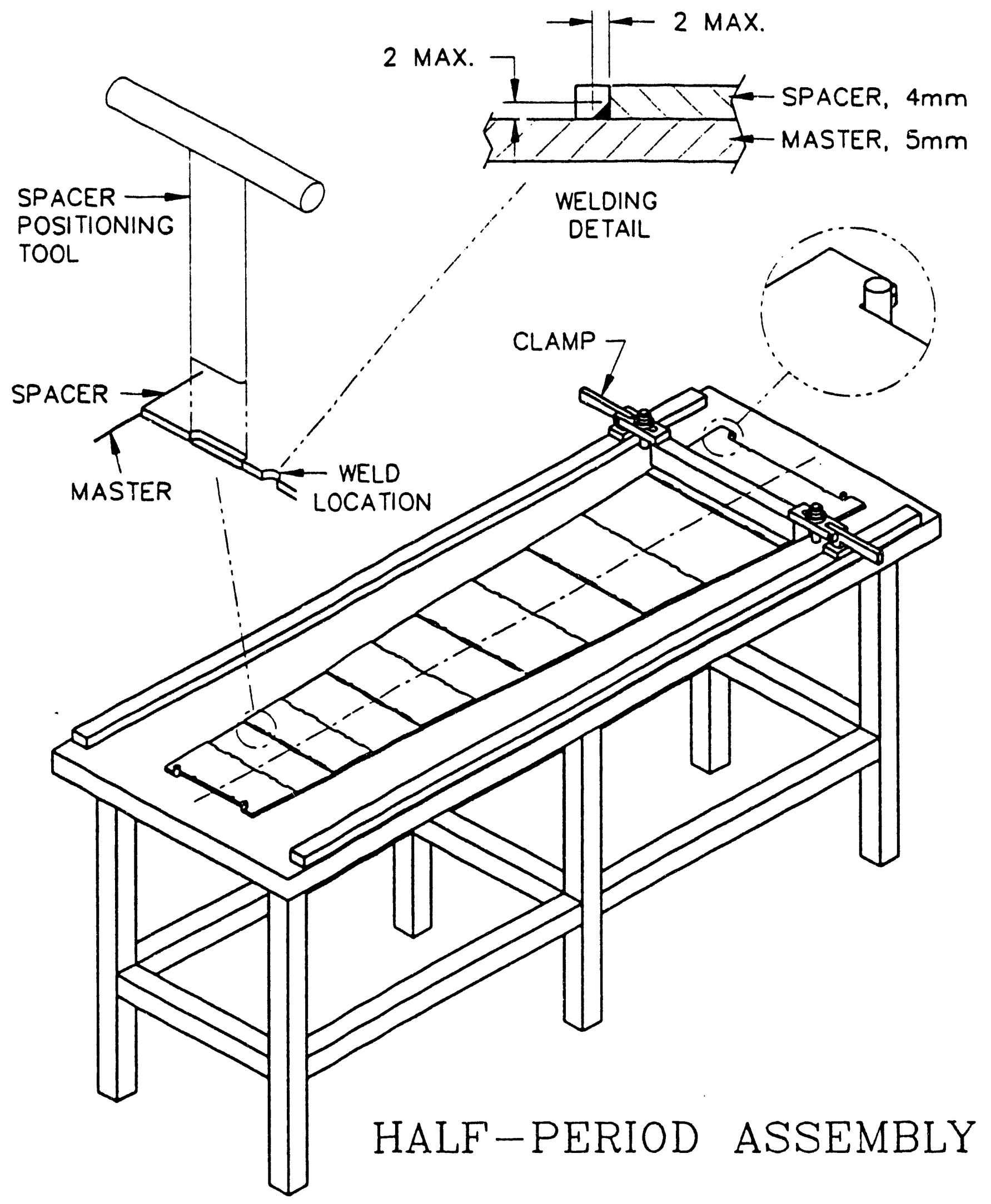




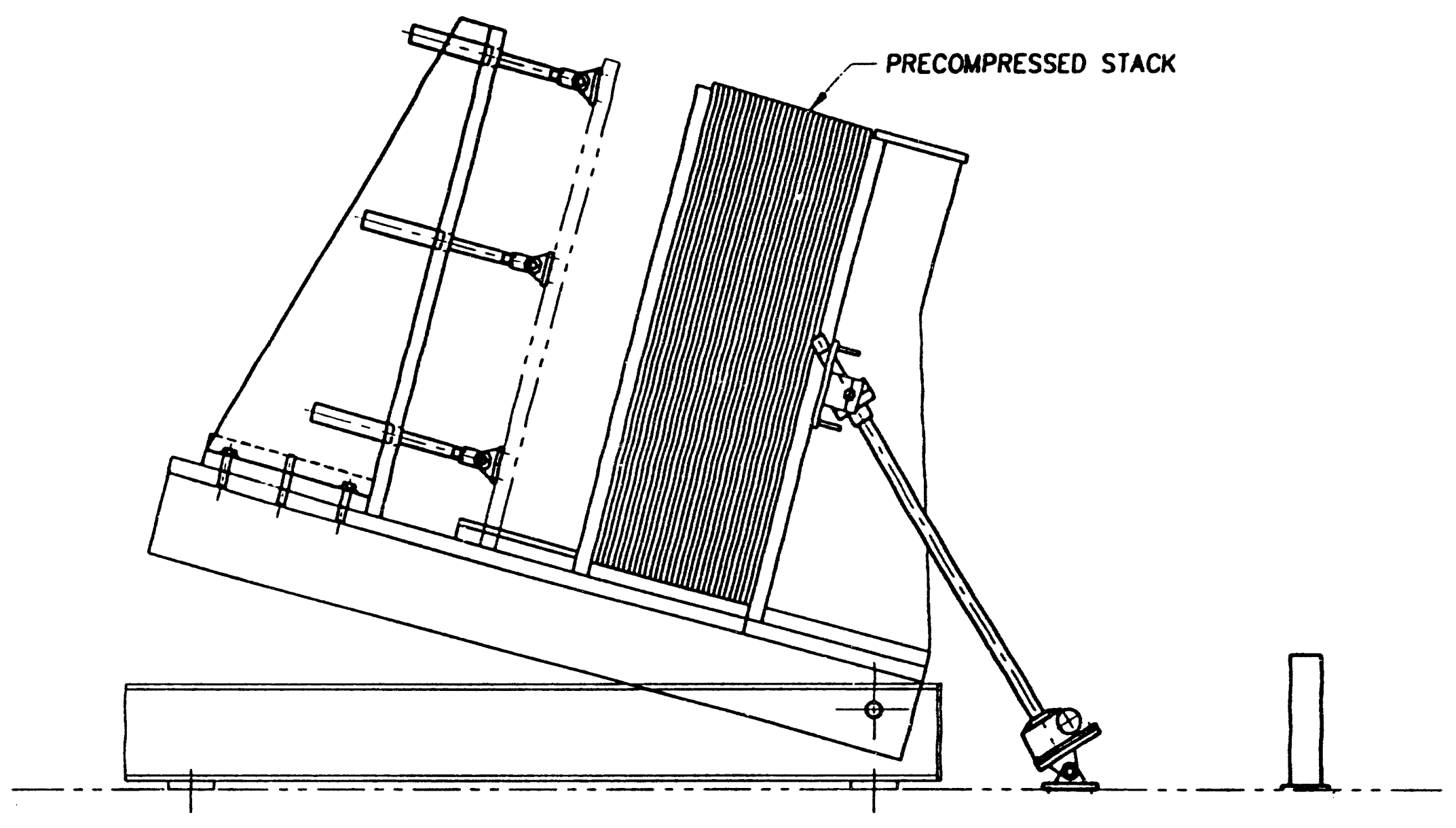

Stacking Fixture Precompression Mode 

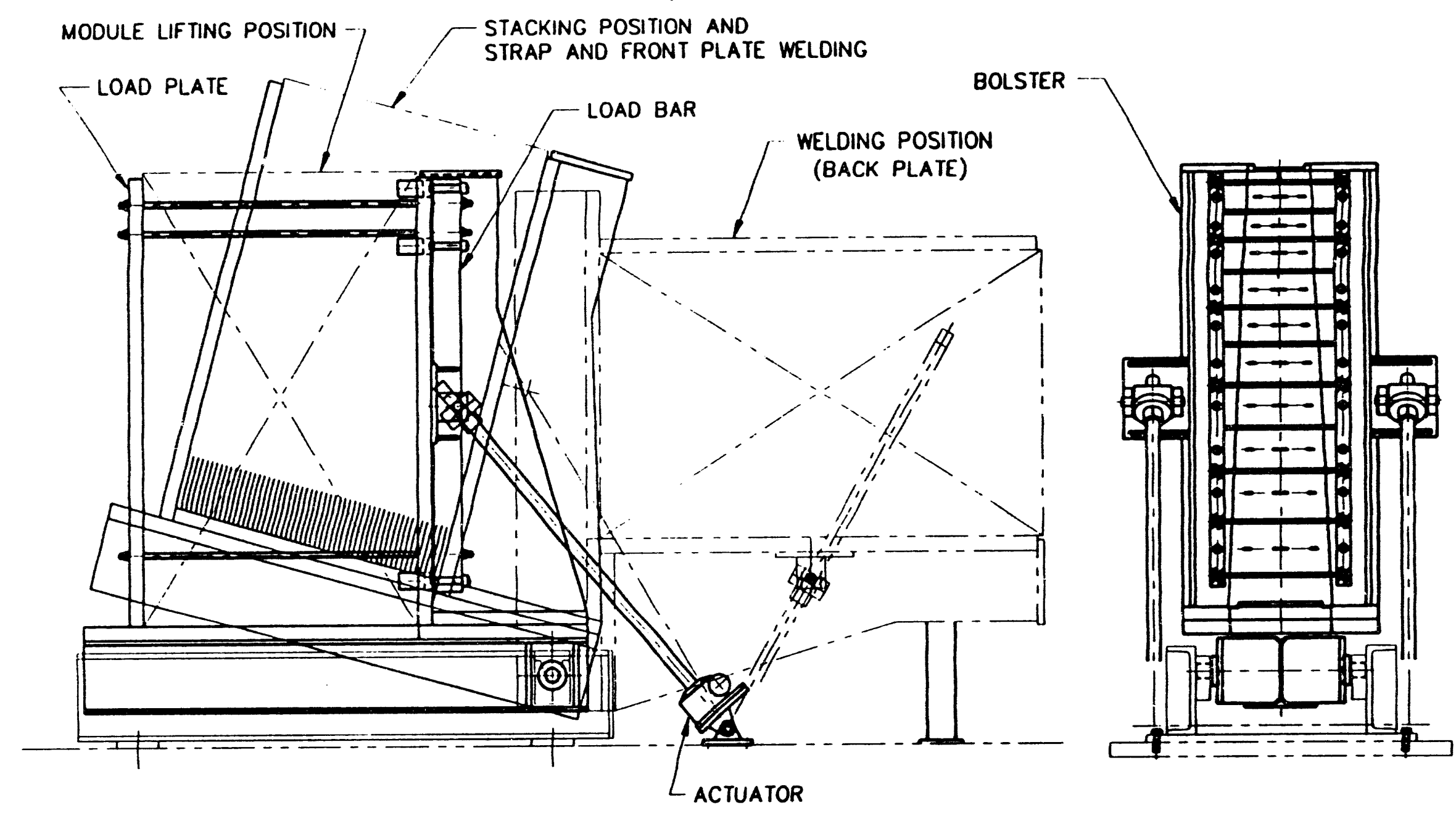

STACKING FIXTURE 


\section{Question \# 5}

What is the welding procedure and possible weld distortions in both designs?

- The procedures and expected distortions are the same for both designs.

- Procedures vary only slightly based on end plate configuration of different submodules as shown in weld samples.

- Welding tests to confirm need for prestress and straps.

- Module is completely stacked and compressed when straps are inserted and welded. 


\section{Question \# 6}

If the spacers are tack welded to the master plates, will there be damage to the surface that will interfere with the tile?

- No surface damage expected if TIG welds are used and contained within the weld slots.

- Local effects of welding can be seen in weld samples.

- Weld procedures will be refined to prevent tile interference. 


\section{Question \# 7}

How will sub-modules be assembled together into a full module, and what are the tolerances that can be achieved in the final assembly?

- Pin location to be match drilled to back beam structure at time of assembly.

- Gaps provide for $\mathrm{Z}$ dimension tolerances of submodule when assembled into full module.

- Front plate to be attached across the submodule boundaries by welding or bolting. 


$$
\begin{aligned}
& =.004 " / \text { SPACER. }= \pm .10 \mathrm{~mm} \\
& \pm .004 " / \text { MASTER }= \pm .10 \mathrm{~mm}
\end{aligned}
$$

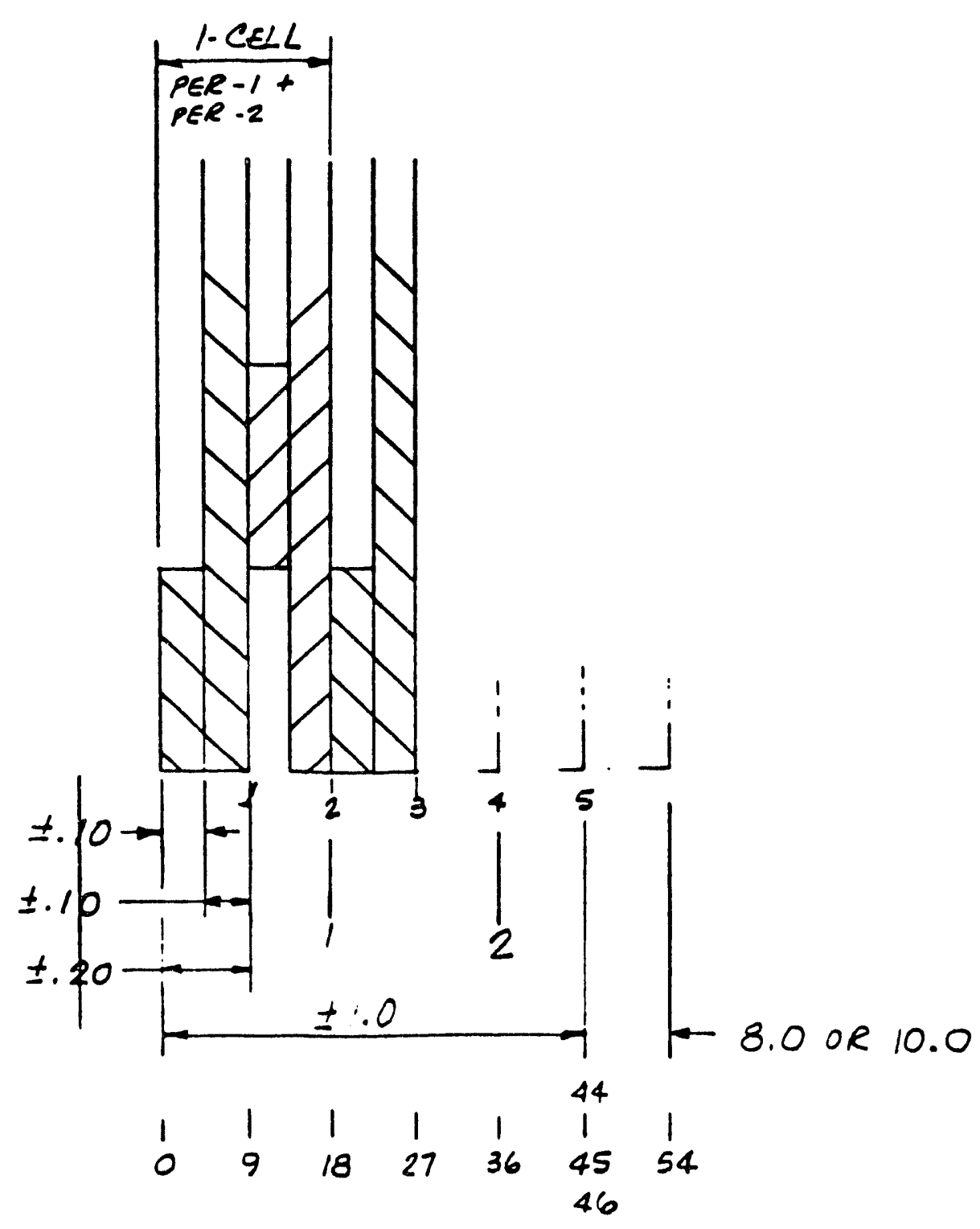

Module Length Control

5 Cell 


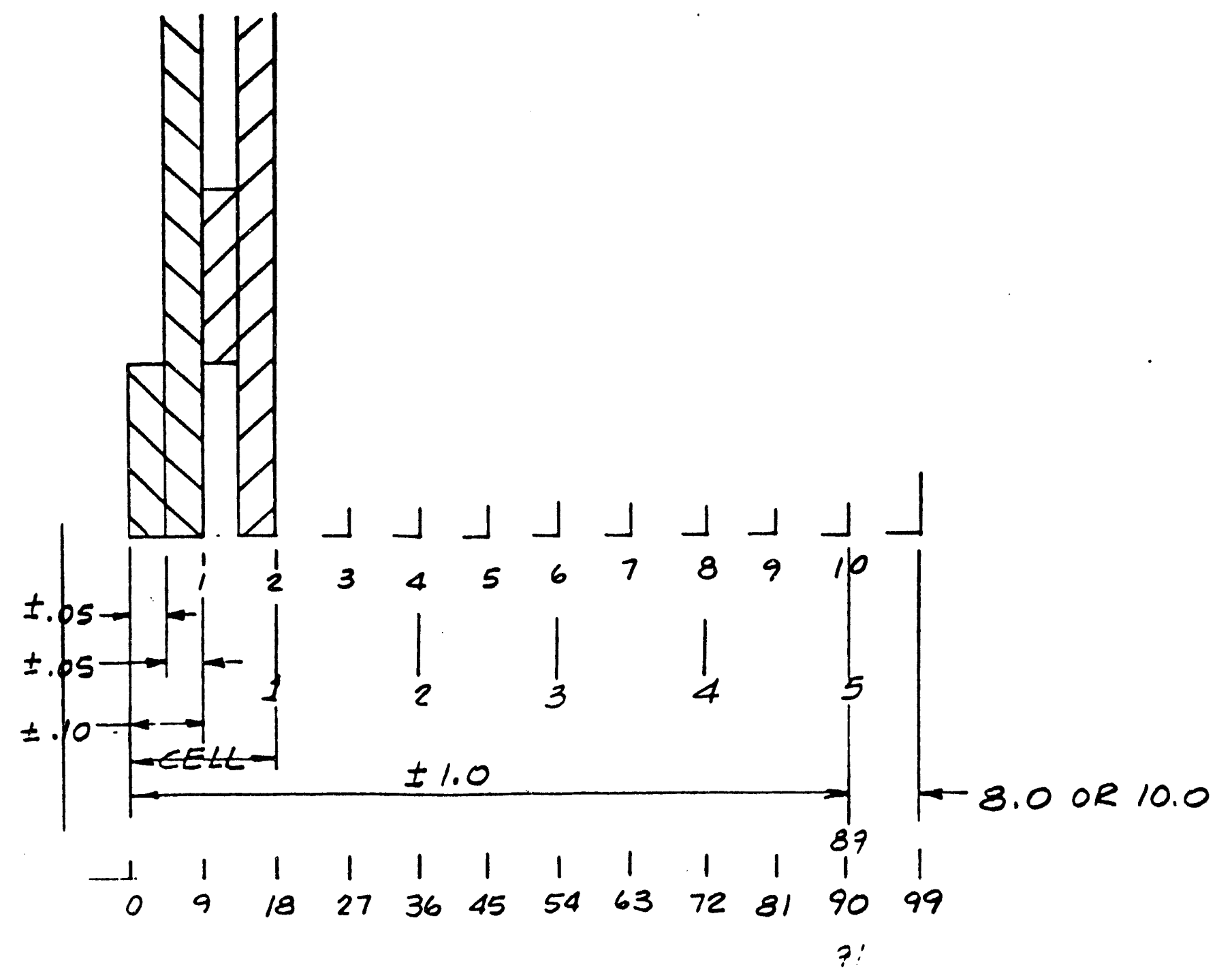

Module Length Control

10 Cell 

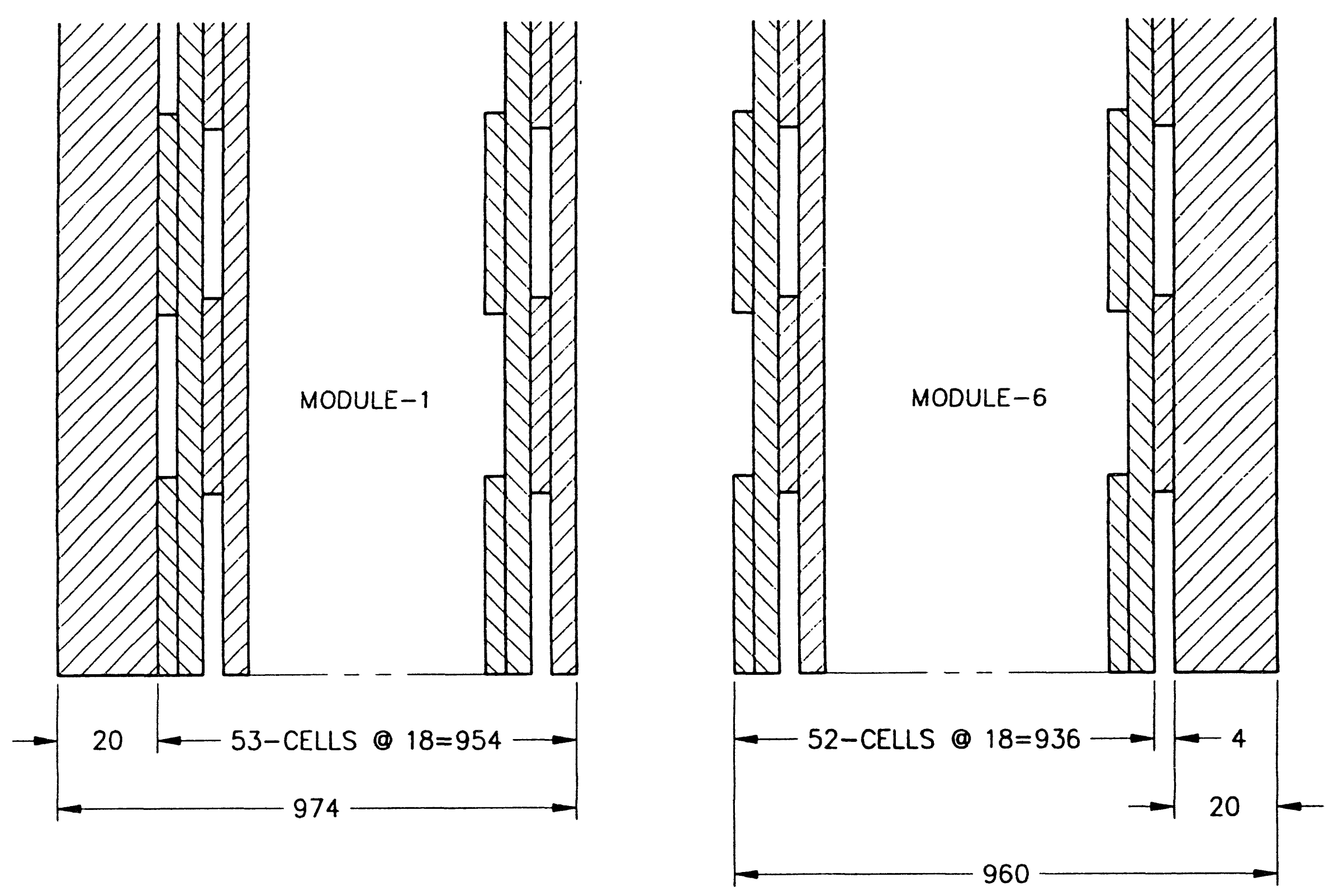

MODULES-1 AND 6 


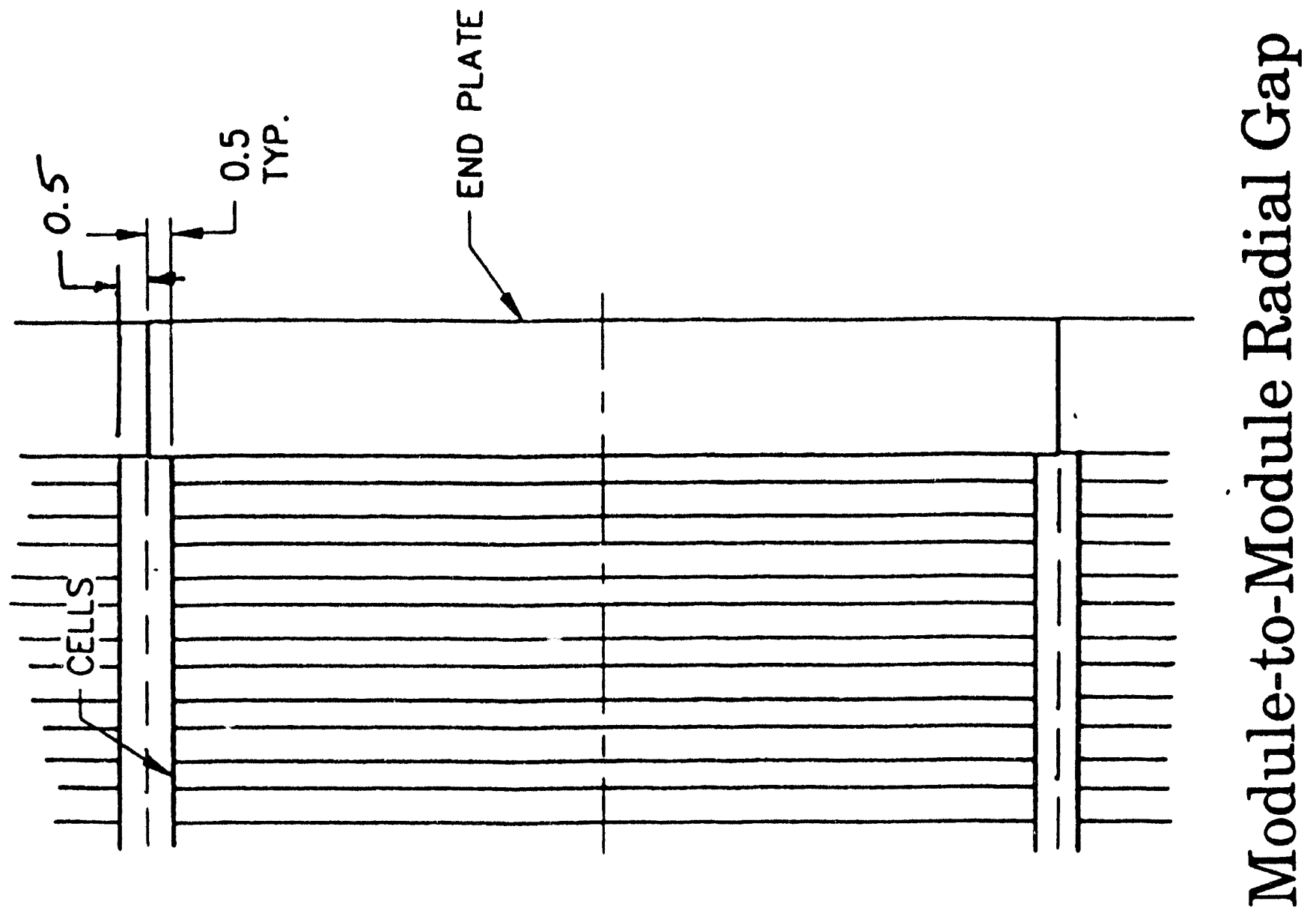




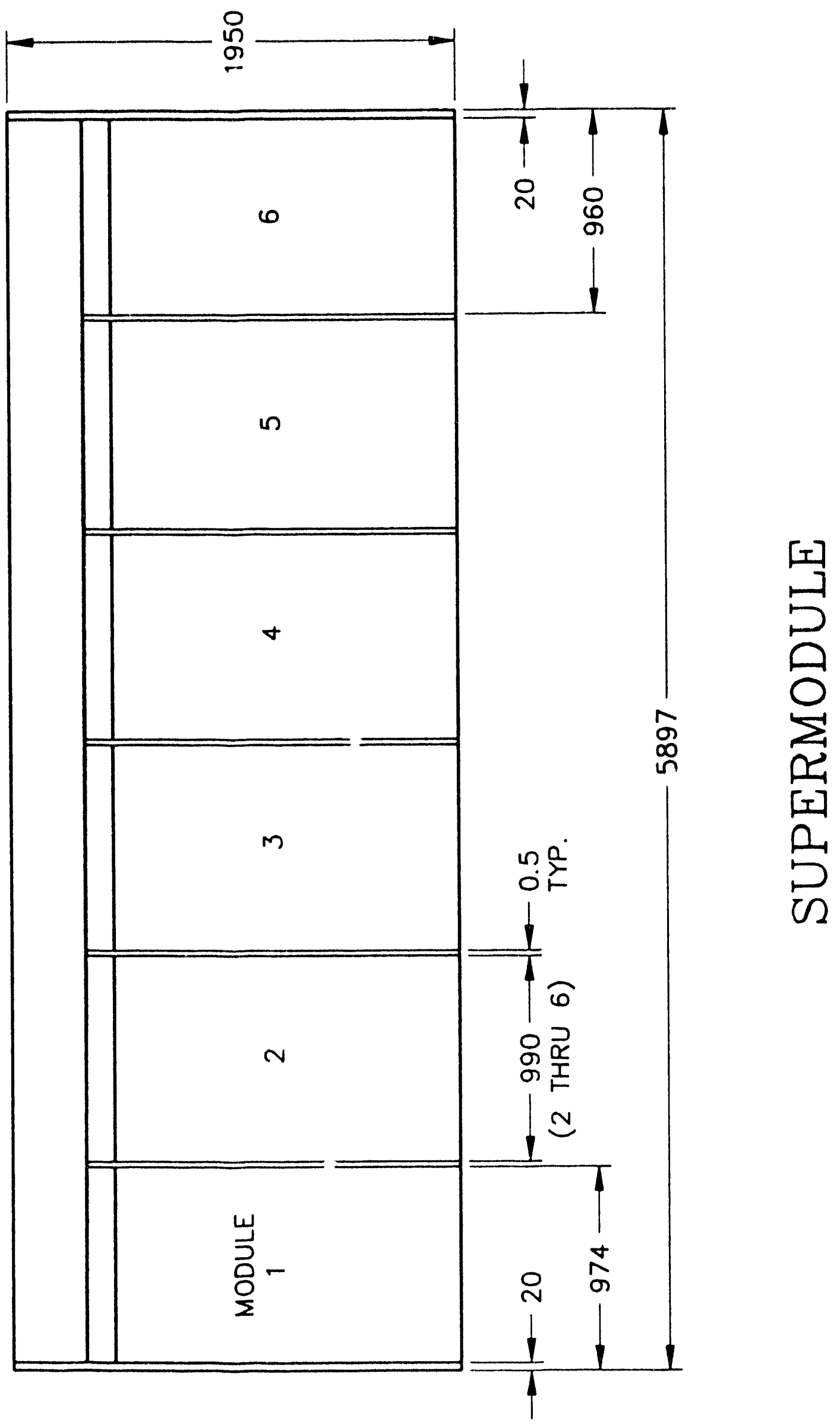


LENGTH OF MODULES:

MODULE-1: $974 \mathrm{~mm}$ (INCLUDES $20 \mathrm{~mm}$ END PLATE)

MODULES-2 THRU 5: $990 \mathrm{~mm}$

MODULE-6: $960 \mathrm{~mm}$ (INCLUDES $20 \mathrm{~mm}$ END PLATE)

PIN HOLES TO BE MATCH DRILLED

GAP BETWEEN MODULES: $.5 \mathrm{~mm}$

FROM BACK BEAM TO MODULES

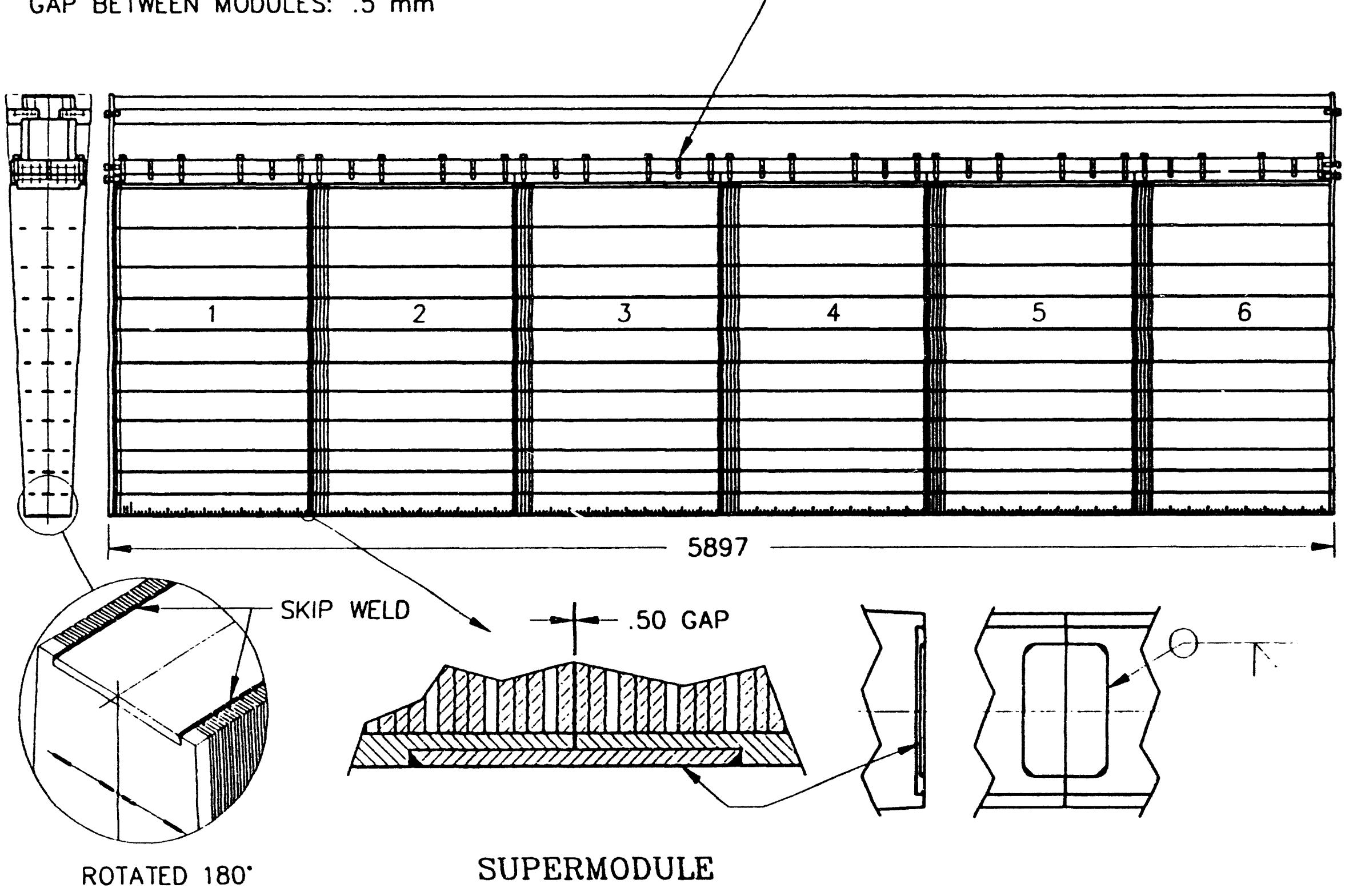




\section{Question \# 8}

How would the straps be tensioned and welded?

- Prestress is considered to not be required, but tests will be conducted.

- Straps only need to be held straight.

- If tests show that prestress is required, we are concerned with possible annealing of heat effected zone.

\section{Strap Tests}

- Tests to determine if strap preload is necessary and if preload is affected by welding.

- Tests assuming different compression loads.

- Tests will vary from no preload to load 1.5 times expected strap load due to stack compression.

- Strain gauge measurements to determine stress on strap during preload and welding. 


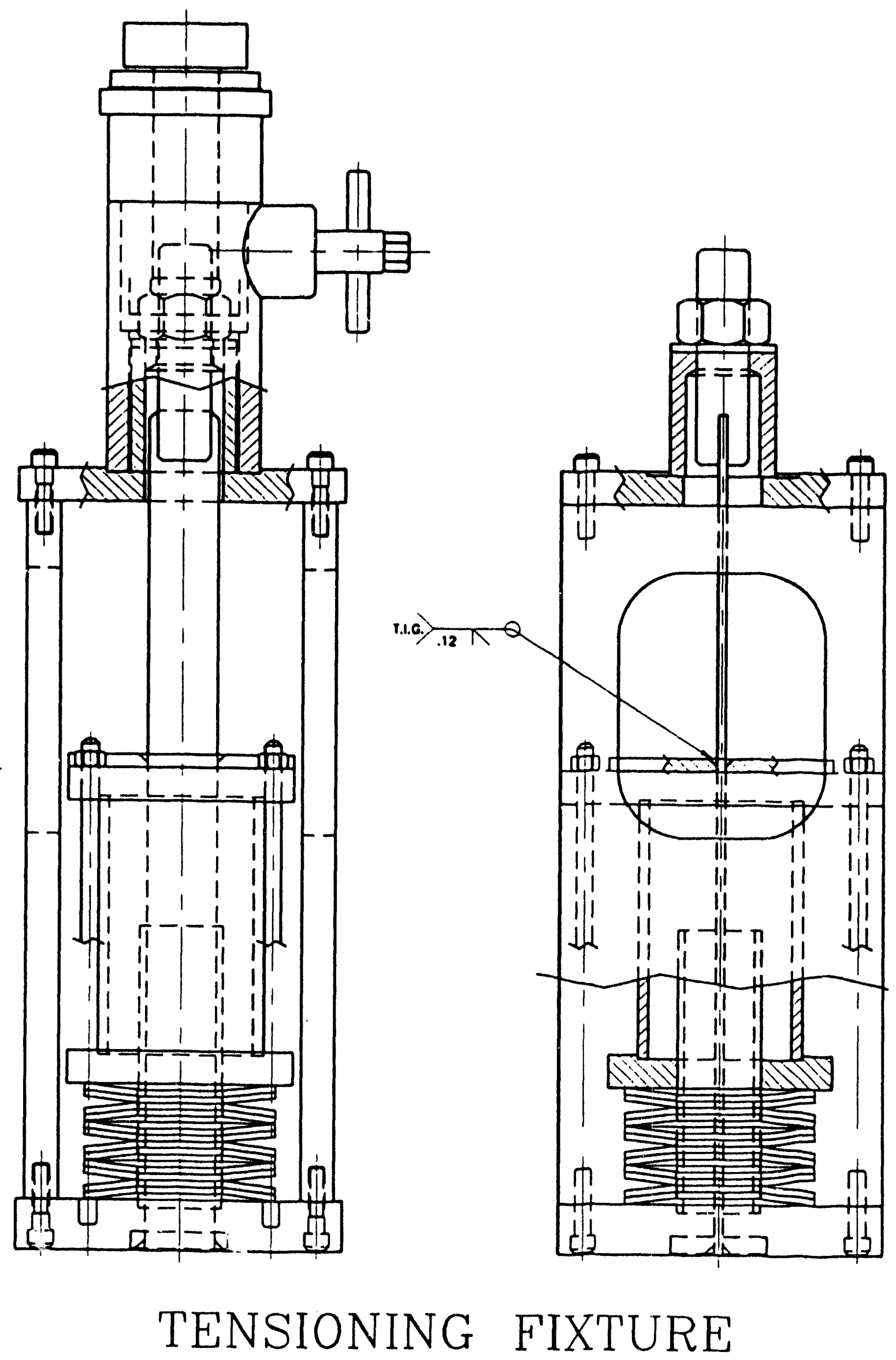




\section{Summary of Rod/Strap Stress and Deformation}

\begin{tabular}{|c|c|c|c|c|c|}
\hline & & \multicolumn{2}{|c|}{ Rod } & \multicolumn{2}{|c|}{ Straps } \\
\hline Module & $\begin{array}{c}\text { Structure } \\
\text { Compressive } \\
\text { Load }\end{array}$ & Stress & Elongation & Stress & Elongation \\
\hline $6 \mathrm{~m}$ module & $\begin{array}{c}.5 \mathrm{MPa} \\
\\
.3 \mathrm{MPa} \\
\text { Single node } \\
\\
5.2 \mathrm{MPa} \\
\text { Multi-node }\end{array}$ & $\begin{array}{c}277.3 \mathrm{MPa} \\
(40,220 \mathrm{psi}) \\
\\
154 \mathrm{MPa} \\
(22,370 \mathrm{psi}) \\
\\
2,860 \mathrm{MPa}^{*} \\
\left(414,800 \mathrm{psi}^{2}\right)\end{array}$ & $\begin{array}{c}2.1 \mathrm{~mm} \\
.081^{\prime \prime} \\
1.1 \mathrm{~mm} \\
.045^{\prime \prime} \\
\\
21.3 \mathrm{~mm} \\
.83^{\prime \prime} \\
\end{array}$ & $\begin{array}{c}39.2 \mathrm{MPa} \\
(5,686 \mathrm{psi}) \\
\\
21.8 \mathrm{MPa} \\
(3,167 \mathrm{psi}) \\
\\
405 \mathrm{MPa}^{*} \\
(58,730 \mathrm{psi}) \\
\end{array}$ & $\begin{array}{c}1.14 \mathrm{~mm} \\
.045^{\prime \prime} \\
.63 \mathrm{~mm} \\
.025^{\prime \prime} \\
11.4 \mathrm{~mm} \\
.45^{\prime \prime} \\
\end{array}$ \\
\hline $1 \mathrm{~m}$ module & $\begin{array}{c}.5 \mathrm{MPa} \\
.06 \mathrm{MPa} \\
\text { Single node } \\
1.1 \mathrm{MPa} \\
\text { Multi-node }\end{array}$ & $\begin{array}{c}277.3 \mathrm{MPa} \\
(40,220 \mathrm{psi}) \\
\\
32.9 \mathrm{MPa} \\
(4,672 \mathrm{psi}) \\
\\
619 \mathrm{MPa} \\
(87,924 \mathrm{psi})\end{array}$ & $\begin{array}{l}2.1 \mathrm{~mm} \\
.081^{\prime \prime} \\
.24 \mathrm{~mm} \\
.009^{\prime \prime} \\
4.5 \mathrm{~mm} \\
.178^{\prime \prime} \\
\end{array}$ & $\begin{array}{c}39.2 \mathrm{MPa} \\
(5,686 \mathrm{psi}) \\
\\
4.4 \mathrm{MPa} \\
633 \mathrm{psi}) \\
\\
82.8 \mathrm{MPa} \\
(11,750 \mathrm{psi})\end{array}$ & $\begin{array}{c}1.14 \mathrm{~mm} \\
.045^{\prime \prime} \\
3 \times 10^{-4} \mathrm{~mm} \\
1.3 \times 10^{-5 "} \\
.6 \mathrm{~mm} \\
.024^{\prime \prime} \\
\end{array}$ \\
\hline
\end{tabular}

* Material will yield. 


\section{Strap Test Sequence}

\begin{tabular}{|c|c|c|c|}
\hline Test \# & $\begin{array}{c}\text { Disk Spring } \\
\text { Compressive Load }\end{array}$ & $\begin{array}{c}\text { Strap Preload } \\
2,487 \mathrm{lbs} . \\
1,128 \mathrm{Kg}\end{array}$ & $\begin{array}{c}\text { Strap Stress } \\
\text { at Preload }\end{array}$ \\
\hline 1 & $.5 \mathrm{MPa}$ & $5,686 \mathrm{psi}$ \\
& & $39.2 \mathrm{MPa}$ \\
\hline 2 & $.5 \mathrm{MPa}$ & $3,731 \mathrm{lbs}$. & $8,529 \mathrm{psi}$ \\
$1,692 \mathrm{Kg}$ & $60 \mathrm{MPa}$ \\
\hline 3 & $.3 \mathrm{MPa}$ & $1,385 \mathrm{lbs}$. & $3,167 \mathrm{psi}$ \\
& & $628 \mathrm{Kg}$ & $22.3 \mathrm{MPa}$ \\
\hline 4 & $.3 \mathrm{MPa}$ & $2,078 \mathrm{lbs}$. & $4,750 \mathrm{psi}$ \\
& & $942 \mathrm{Kg}$ & $33.5 \mathrm{MPa}$ \\
\hline 5 & $5.2 \mathrm{MPa}$ & $25,694 \mathrm{lbs}$. & $58,730 \mathrm{psi}$ \\
& & $11,654 \mathrm{Kg}$ & $414 \mathrm{MPa}$ \\
\hline 6 & $.06 \mathrm{MPa}$ & $277 \mathrm{lbs}$. & $633 \mathrm{psi}$ \\
& & $125 \mathrm{Kg}$ & $4.4 \mathrm{MPa}$ \\
\hline 7 & $.06 \mathrm{MPa}$ & $415 \mathrm{lbs}$. & $950 \mathrm{psi}$ \\
& & $188 \mathrm{Kg}$ & $6.7 \mathrm{MPa}$ \\
\hline 8 & $1.1 \mathrm{MPa}$ & $5,140 \mathrm{lbs}$. & $11,750 \mathrm{psi}$ \\
& & $2,331 \mathrm{Kg}$ & $82.8 \mathrm{MPa}$ \\
\hline 9 & $1.1 \mathrm{MPa}$ & $7,711 \mathrm{lbs}$. & $17,625 \mathrm{psi}$ \\
& & $3497 \mathrm{Kg}$ & $124 \mathrm{MPa}$ \\
\hline 10 & $5.2 \mathrm{MPa}$ & 0 & 0 \\
\hline
\end{tabular}




\section{Strap Test Status}

- Basic frame components completed by the University of Chicago.

- Estimates received by Argonne for balance of parts.

- Technicians will complete parts in 3 weeks.

- Expect to complete tests by next Atlas meeting. 


\section{Cost in U.S. Dollars for Absorber Plates and Tooling}

Plates

Spacers

Masters

(Note - plate costs include material estimated at $\$ .55 / \mathrm{kg}$ )
$\$ 234,766.00^{*}$

$\$ 732,720.00^{*}$

Production Tooling

Spacers

Masters
$\$ 42,000.00 *$

$\$ 40,472.00^{*}$

Assembly Fixtures

Stacking and welding

$1 / 2$ period assembly est. $\$ 150,000.00$ est. $\$ 15,000.00$

* Supported by vendor quotations. 
(0). (0)-

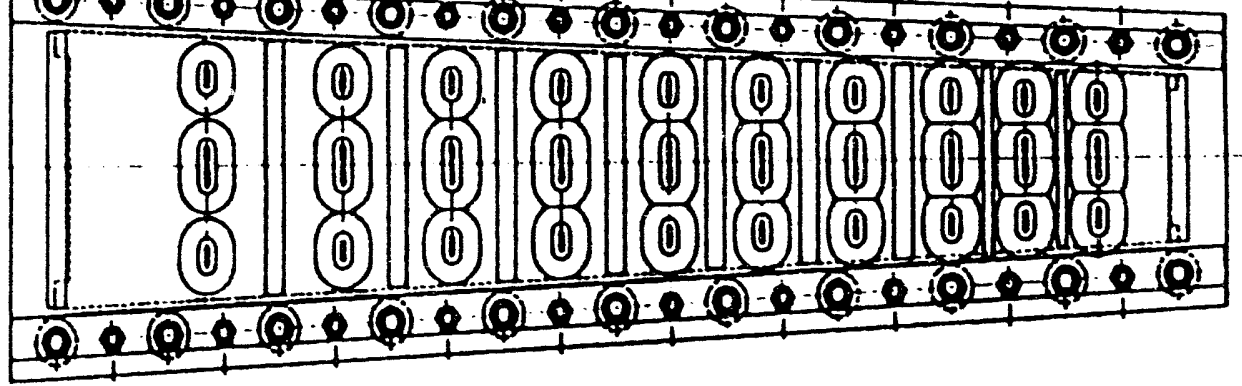

i.

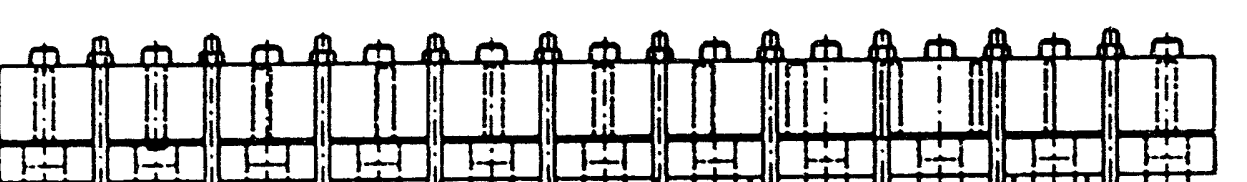

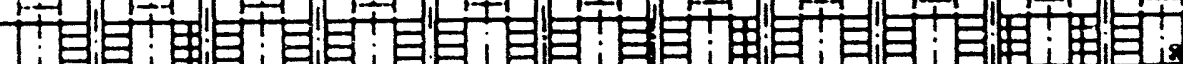

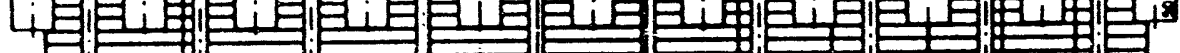

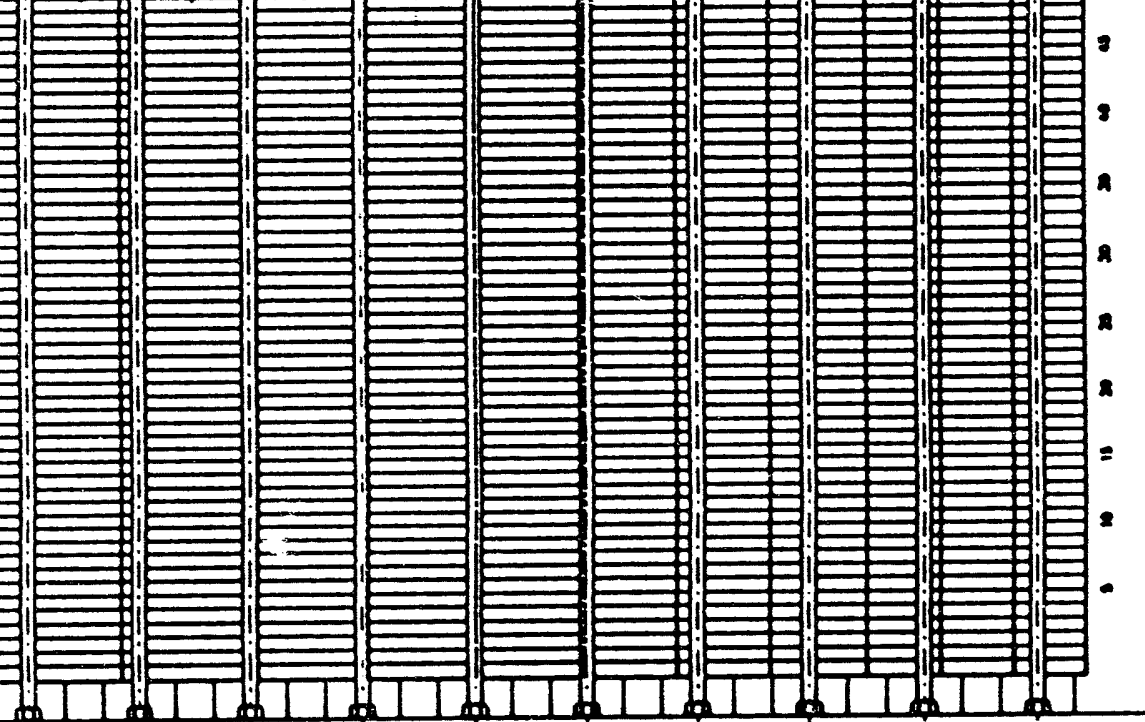

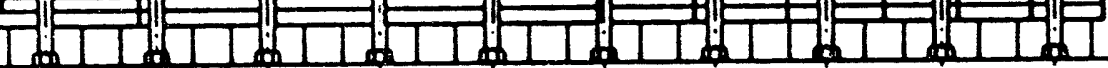

$1 \mathrm{~m}$ PROTOTYPE MODULE COMPRESSION FIXTURE
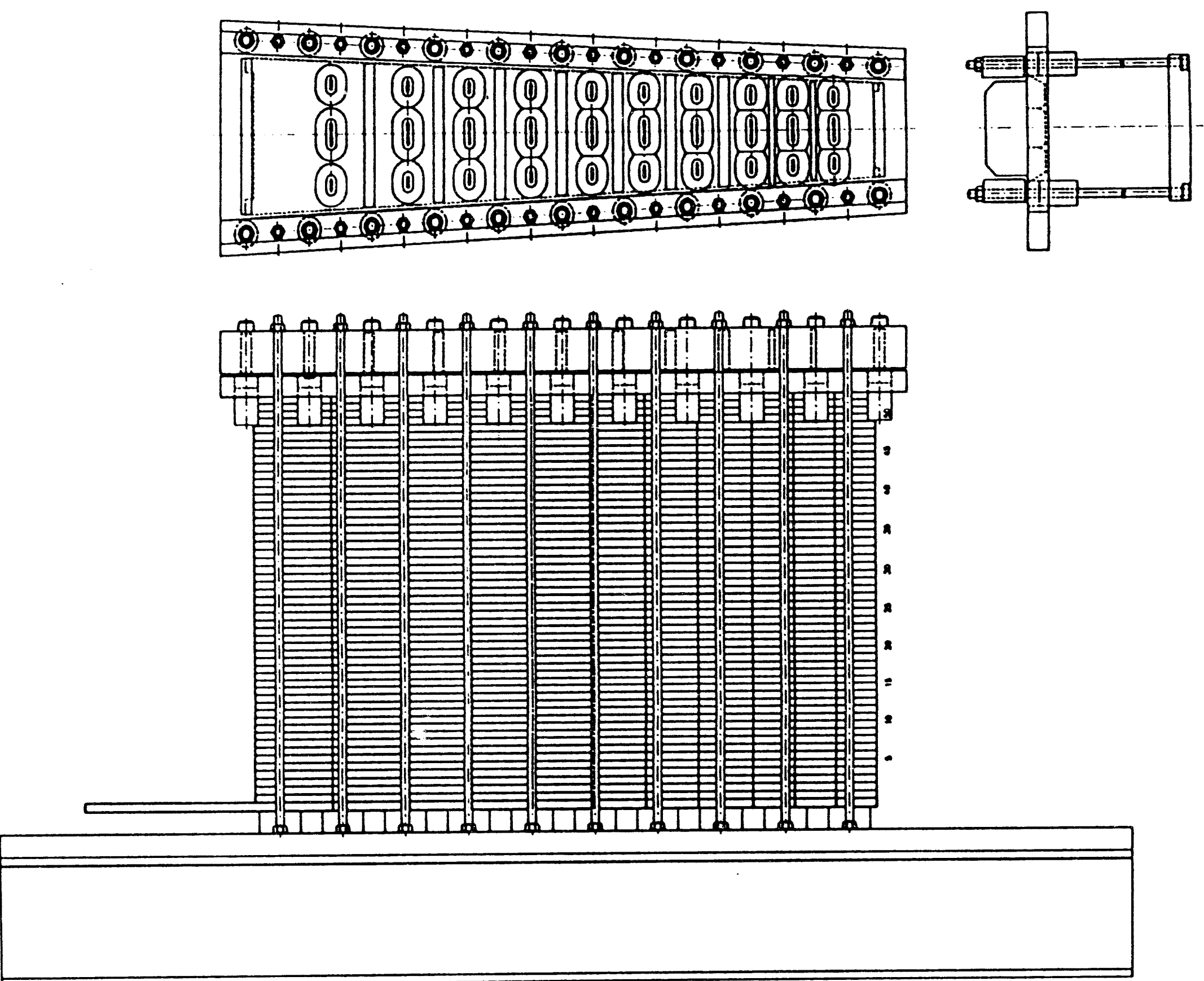


\title{
ATLAS One Meter Prototype Cost
}

\author{
Mechanical
}

Norman F. Hill

10 June 1994

\begin{tabular}{|r|l|r|r|r|}
\hline & & Material & Labor & TOTAL \\
\hline 1 & Master Plates & $\$ 1078.00$ & $\$ 18,920.00$ & $\$ 19,998.00$ \\
\hline 1a & Adjustment Plates & $\$ 786.00$ & $\$ 6,000.00$ & $\$ 6,786.00$ \\
\hline 2 & Spacer Plates & $\$ 539.00$ & $\$ 49,375.00$ & $\$ 49,914.00$ \\
\hline 3 & Straps & $\$ 50.00$ & $\$ 2,200.00$ & $\$ 2,250.00$ \\
\hline 4 & Inner Radius Plate & $\$ 1500.00$ & $\$ 2000.00$ & $\$ 3,500.00$ \\
\hline 5 & Outer Radius Plate & $\$ 1500.00$ & $\$ 2000.00$ & $\$ 3,500.00$ \\
\hline 6 & $\begin{array}{c}\text { 1/2 Period Subassembly } \\
\text { Tooling }\end{array}$ & $\$ 20,000.00$ & & $\$ 20,000.00$ \\
\hline 7 & $\begin{array}{l}\text { Wtacking Press } \\
\text { (assuming ZEUS fixture model) }\end{array}$ & $\$ 35,000.00$ & & $\$ 35,000.00$ \\
\hline 8 & Inner and Outer Plate Welding & & $\$ 8000.00$ & $\$ 8000.00$ \\
\hline 9 & Strap Welding & & $\$ 2,000.00$ & $\$ 2,000.00$ \\
\hline & GRAND TOTAL & $\$ 60,453.00$ & $\$ 130,495.00$ & $\$ 190,948.00$ \\
\hline
\end{tabular}



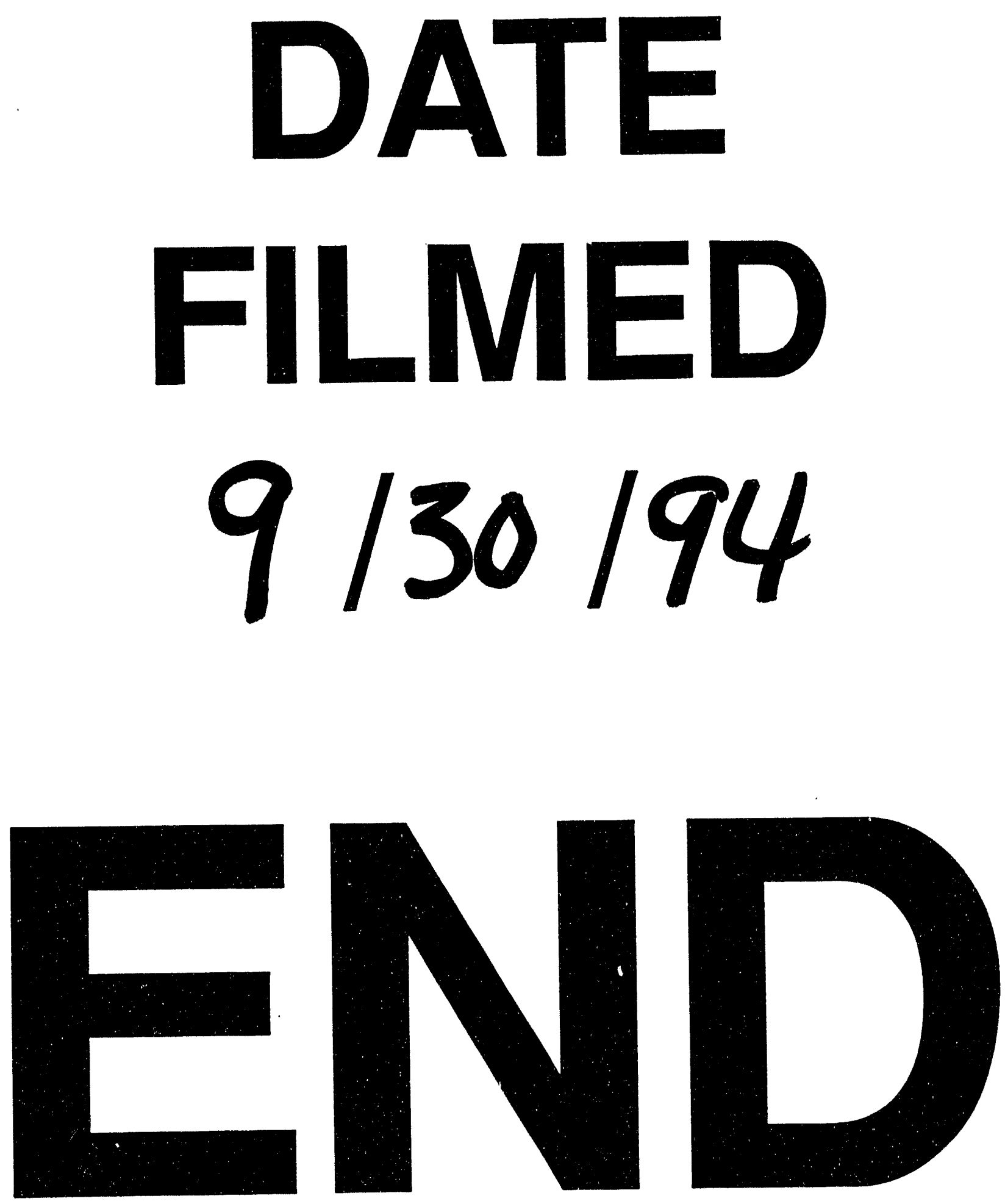


$$
\ldots
$$

